
FUNDAMENTOS, TEORIAS E ASPECTOS METODOLÓGICOS DISCIPLINARES APLICADOS NA BIÔNICA E BIOMIMÉTICA 


\section{SOBRE OS AUTORES}

Luiz Vidal Negreiros Gomes I luizvidalgomes@gmeil.com

Lattes: http://lattes.cnpq.br/8337493682978892

Bacharel em Desenho Industrial (BDi, UFPE, 1980); Mestre em Engenharia de Produção (MSc, COPPE/UFRJ, 1986); Doutor em Filosofia (PhD, University of London, 1991). Realizou estágios pós-doutorais no PEP Gente/Coppe, UFRJ (1999); e na Open University (2007) Inglaterra. Foi professor adjunto dos Cursos de Desenho Industrial da UFPE (1983-1993) e da UFSM, RS, (1993-1994); titular do Departamento de Engenharia Industrial da UFSM, (19942004); visitante e efetivo do Curso de Design de Produto da UCS, RS (2003-2005); e professor titular da Faculdade de Design UniRitter (2004-2011). Foi Coordenador do PPGEP/UFSM, RS (1994-1998); do Curso de Especialização em Design (2006-2009) e do Curso de Mestrado UniRitter, RS (2009-2011). Diretor da sCHDs Editora, POA-RS (2001-2012). Foi professor das disciplinas de Criação e Redação Publicitária (Publicidade e Propaganda) e de Tópicos Avançados em Administração na Unidade de Ensino Superior de Feira de Santana, UNEF, Bahia, Brasil. Foi Professor Adjunto para Desenho, Teoria e Conhecimento (Mestrado) e de Desenho Básico (Graduação em Engenharia), da Universidade Estadual de Feira de Santana, UEFS, BA (2011-2014). Desde março de 2014, Professor Adjunto da Universidade do Estado do Rio de Janeiro, Escola Superior de Desenho Industrial.

Hugo Sorio Scheid Gomes I scheidhugos@gmail.com

Lattes: http://lattes.cnpq.br/6134738499413787

Possui graduação em Engenharia Mecânica pela Universidade Federal de Santa Maria (1999). Atualmente é Gerente de Engenharia da John Deere Brasil. Tem experiência na área de Engenharia Mecânica, com ênfase em Projetos de Máquinas.

Alexandre Oliveira Gomes I aleoli05@gmail.com Lattes: http://lattes.cnpq.br/4920816501807863 Possui Doutorado em Engenharia Agrícola, na Área de Mecanização Agrícola (2008); Mestrado em Administração, Área de Finanças (2008); Mestrado em Engenharia de Produção, Área de Planejamento Estratégico (2002); Especialização em Estatística e Modelagem Quantitativa, na Área de Séries Temporais (2009), Graduação em Engenharia Mecânica (2001), Graduação em Administração (2002), Graduação em Ciências Contábeis (2006), Graduação em Ciências Econômicas (2014) e Técnico em Mecânica (1993); todos pela Universidade Federal de Santa Maria (UFSM). Professor Adjunto IV na Universidade Federal do Pampa (UNIPAMPA). Já forneceu consultoria à 205 empresas, foi extensionista da Secretaria de Desenvolvimento e Assuntos Internacionais do Governo do Estado do Rio Grande do Sul (SEDAI/RS) junto à UNICRUZ/RS e coordenador de Núcleos de Pesquisa e Extensão e de cursos sobre Engenharia Econômica e Mercado de Capitais, atuando como docente há 17 anos em instituições de ensino técnico, superior, e pós-graduação, como UNIPAMPA/RS, UFSM/RS, FAPAS/RS, UNIFRA/RS, FAMES/RS, FISMA/RS e FACISA/CELER/SC. Tem experiência nas áreas de Engenharia de Produção, Projeto de Produto e Administração Financeira, com ênfase em Planejamento Estratégico e Orçamento. 


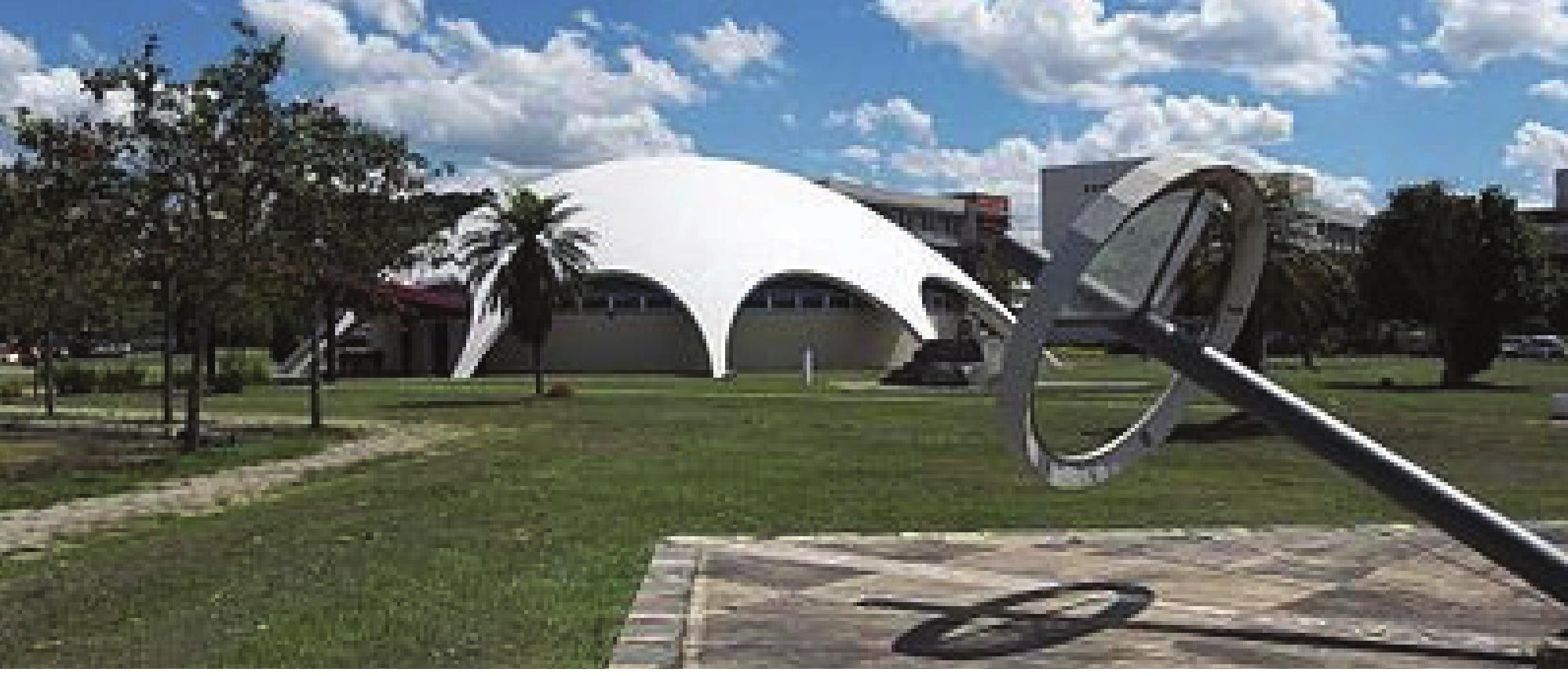

\title{
Biomimética: Estudo de Estruturas Naturais para Desenho de Produtos Industriais
}

\author{
Biomimicry: Study of Natural Structures for Industrial \\ Products Design
}

Luiz Vidal Negreiros Gomes I Hugo Sorio Scheid I Alexandre Oliveira

\section{Resumo}

Este texto tem como objetivo relatar as experiências com o tema Biônica, à época assim denominado, realizadas com pesquisa de alunos do Curso de Engenharia Mecânica envolvidos com o Projeto REENGE (1996-1997), na Universidade Federal de Santa Maria, UFSM, RS. Aqui, apresentam-se descrições metodológicas de táticas procedimentais e de técnicas operacionais para o desenvolvimento de pesquisas associativas entre os seres vivos e projetos de produtos industriais.

Palavras-chaves: Biônica, Biomimética, Desenho Industrial e Engenharia.

\section{Abstract}

This paper aims to report on the experiments with the Bionic theme, at the time so called, carried out with research of students of the Mechanical Engineering Course involved with the REENGE Project (1996-1997), at the Federal University of Santa Maria, UFSM, RS. Here, we present methodological descriptions of procedural tactics and operational techniques for the development of associative research among living beings and industrial product designs.

Keywords: Bionics, Biomimicry, Industrial Design and Engineering. 


\section{INTRODUÇÃO}

\section{Da biologia à biomimética, passando pela biônica}

Este texto tem como objetivo relatar as experiências com o tema Biônica realizadas com pesquisa de alunos do Projeto REENGE (1996-1997), na Universidade Federal de Santa Maria. Aqui, apresentam-se descrições sumárias de táticas e técnicas metodológicas usadas em pesquisas associativas entre os seres vivos e projetos de produtos industriais.

A palavra inglesa bionics' formada da justaposição do elemento de composição "bio" (do grego bíos, "vida") com parte da palavra (electr) onics, foi tomada para se fazer calque linguístico do vocábulo português "Biônica". No Brasil, a palavra Biônica, por mais de três décadas, serviu para identificar "O estudo das funções, características e fenômenos observados nos seres vivos, a fim de aplicar tais conhecimentos na idealização de novas técnicas e construção de novos aparelhos e máquinas, em especial no campo da eletrônica"2. Todavia, nem no Aurélio, dicionário que, em sua segunda edição, apresenta-nos essa denotação, tampouco os glossários de língua inglesa consultados, há indicação de quem, pela primeira vez, usou os termos bionics/biônica.

Essa informação vamos encontrar no livro Bionics (1968) de Lucien Gérardin (1923-1995), engenheiro francês da Ecole Supérieure d'Electricité de Paris. Dr. Gérardin, diretor de centro de estudos e responsável pela pesquisa em grande empresa francesa de eletrônicos, ensina que uma das primeiras pessoas a utilizar o termo bionics foi o major Jack E. Steel e da Divisão Aeroespacial da Força Aérea Norte Americana.

Em agosto de 1958, major Steel e conotava a Biônica como "a ciência dos sistemas cujas funções são baseadas em seres vivos, ou que tem características e semelhanças a estes", e não apenas como o estudo de algo relativo aos seres vivos para aplicação na indústria eletrônica.

Aqui, a Biônica é um tipo de metodologia que se presta tanto para matemáticos, físicos e químicos, quanto para profissionais das Engenharias, de Arquitetura e, em especial, de Desenho Industrial, designers desenhadores de projeto de produto.

A Biônica, ou Biónica em português castiço, mesmo com o seu atual codinome "Biomimética"3, quando usada em disciplinas especiais de criatividade ou inclusas em práticas corriqueiras de projeto de produto em cursos de Design brasileiros, são de suma importância. Independentemente de sua atual graça didática, a metodologia propicia entrecortes de diversos saberes.

No ano de 1974, David H. Offner4, professor de engenharia mecânica da Universidade de Illinois, citando von Gierke e o seu colega Oiestreicher, definia a Biônica como "o estudo dos sistemas naturais com objetivo de descobrir novos princípios, técnicas e processos para serem aplicados à tecnologia humana. A Biônica analisa quantitativamente os modelos biológicos, seus princípios e capacidade funcional com o objetivo de extrair inspiração e novas relações para produtos com similares características" ${ }^{\prime \prime}$. Este conceito seria diretamente assimilado por Victor 
Papanek (1971), Gui Bonsiepe (1976), Fabricio Vanden Broeck (1981), e Carmelo di Bartolo $(1981 ; 1986)^{6}$.

A aprendizagem de projeto de produto industrial, seja Engenharia, Arquitetura, ou Desenho industrial tende a ser detalhado em disciplinas específicas e, em sua maioria, desassociadas em suas matérias. Há um consenso, contudo, de que o conhecimento desenvolvido em disciplinas criativas de Biônica ou em cursos de criatividade baseados na Biomimética, inclinam-se para o efetivo relacionamento de distintos saberes e, cada vez mais, no necessário interrelacionamento profissional e, mais, num saudável compartilhamento, dividido em distintos momentos de projetação. (Figura 1)

Entretanto, não há registros oficiais de quem proferiu ou escreveu pela primeira vez a palavra Biônica no Brasil. 0 que sabemos é que, em meados dos anos 1970, na Escola Superior de Desenho Industrial, ESDI, da Universidade do Estado do Rio de Janeiro, UERJ, e na Escola de Belas Artes da Universidade Federal do Rio de Janeiro, UFRJ, o Prof. Roberto Verschleisser já realizava, em suas disciplinas de Desenho Industrial, exercícios relacionados à educação criativa e projetual com base em aprendizados inspirados e tomados da fonte da Natureza.

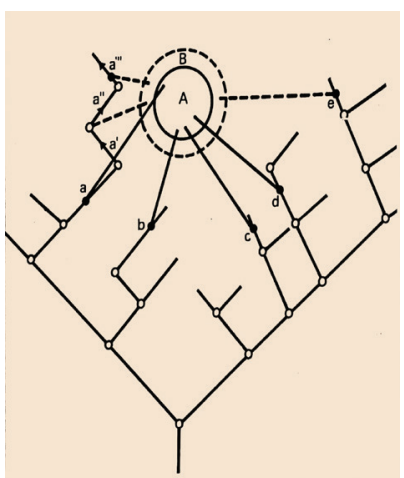

Figura 1: Diferenças esquemáticas entre Ciências Puras ou de Origem (A); Ciências de Interseção ou Cruzamento $(a, b, c, d, e$, f); e Ciências de Propagação ou Difusão (B) de conhecimento em Biônica. (Baseado em Gérardin, 1968).

Temos informação de que, no início dos anos 1980, Prof. Carlos Antonio Ramirez Righi, então professor do Curso de Desenho Industrial da Universidade Federal de Pernambuco, CDI/UFPE, demonstrava valorizar didaticamente a Biônica, pois foi o responsável por indicar a inclusão do tema como um dos pontos para a prova escrita de concurso destinado à seleção de professor para projeto de produto da UFPE.

Sabe-se também que, no segundo semestre de 1984 , alunos do $7^{\circ}$ período do CDI/UFPE realizaram Minicurso Experimental em Biônica. E, ainda no âmbito da UFPE, Recife, PE, foi fundado o Grupo de Estudos em Biônica, em 13 de setembro de 1986'. Esse grupo congregava alunos e professores do CDI/UFPE que, em junho desse mesmo ano, haviam participado do Primeiro Curso de Atualização em Biônica, promovido pelo Laboratório de Desenvolvimento de Produto/Desenho Industrial (LDB-DI), em seu Centro de Capacitação de Docentes de Desenho Industrial de Santa Catarina, Canasvieiras, Florianópolis.

Esse curso, pioneiro no Brasil, foi ministrado pelo Prof. Fabricio Vanden Broeck da Universidade Autônoma Metropolitana da Cidade do México. Dele participaram professores de várias instituições brasileiras que oferecem curso de bacharelado em Desenho Industrial. Muitos desses professores8 foram os autores de ideias seminais para o desenvolvimento da Biônica em seus estados. $\mathrm{Na}$ atualidade, temos no Brasil professores dando continuidade aos projetos de produto baseados na metodologia Biônica. Esses professores, alguns com título de Mestre obtido em uma das escolas de Design - Istituto Europeo di Design, Milão, na Itália - de maior importância nos anos de 1980.

Neste texto, procuramos caracterizar a Biônica como "didática" apropriada à formação de futuros profissionais e professores de projeto de produto em Engenharia, Arquitetura e Desenho Industrial, pois essa metodologia, inspirada nos elementos vivos, pode ser compreendida como o estudo das: (i) associações 
de formas que configuram, funções que locomovem, e informações que revestem os seres vivos em seu ambiente natural; (ii) organizações de dados e de informações sobre seres vivos, cujos princípios embasam certos princípios científicos, regendo, assim, configurações artificias que podem ser aplicados mimeticamente em desenhos de produtos; e (iii) aplicações da capacidade intelectocriativa e da habilidade manual plasmativa, em compreender a Natureza e gerar conhecimento criativo (inventivo/inovativo) relacionados ao projeto para o desenho de produtos industriais.

Antes de adentarmos nas pesquisas, ressaltamos que a motivação para este texto sobre Biônica se encontra no fato de que esta técnica, com ou sem este nome, tem sido utilizada pelo ser humano desde os primórdios de sua existência, por exemplo, a pua de uma lança lembra um espinho de um limoeiro. No século XX, mesmo antes de o Major Steele ter utilizado o termo bionics, em 1943, os cientistas McCulloch e Pitts "formularam o primeiro modelo do neurónio formal (baseados na concepção dos neurônios de Freud em 1895) tema que provem de diferentes fontes: neurociências, computação, matemática, pesquisa operacional, física, estatística"10. Todas as pesquisas relativas à Biônica.

Pioneiros da aviação, como o alemão Otto Lilienthal (1848-1896) e o francês Clément Ader (1841-1925), seguiram o exemplo de Da Vinci observação das asas do morcego - na construção do planador Éole de Ader, de 1890. Mas não só mamíferos voadores inspiraram e inspiram desenhadores e engenheiros para o avanço de seus inventos e aplicação em produtos. A revista Globo Ciência, outubro de 1994, também informa que $\mathrm{H}$. Hertel, do Instituto de Aeronáutica de Berlim, Alemanha, propôs uma depressão na cabine de pilotagem de aviões comerciais inspirada na cabeça e nas narinas do delfim. Desse modo, muito se tem corrigido das perturbações no fluxo de ar, facilitando-se a navegação aérea. ${ }^{11}$

"Um engenheiro alemão de hidrodinâmica de fluidos demonstrou, no final dos anos de 1950, que no deslocamento de golfinhos, a resistência da água é dez vezes menos elevada que por um modelo artificial do mesmo tamanho e forma, recoberto de plástico"12.

Essa descoberta já resultou em uma série de pesquisas para se conhecer melhor o sistema de propulsão e hidrodinâmica dos golfinhos com o objetivo de aplicar tais princípios ao desenho de projetos de produtos náuticos.

Mais recentemente a cibernética13 tem se utilizado de incontáveis sistemas naturais para a criação de novos produtos. Por exemplo, sob esse enfoque, poderíamos citar a câmara de máquinas fotográficas modernas, com seus diafragmas comandados por fotocélulas, que nada mais são do que uma cópia do olho humano, onde a abertura da pupila também varia com a intensidade da luz. Também podemos mencionar o caso do radar, inspirados na audição dos morcegos, ou o sonar, em que os golfinhos são especialistas. Caso notável é o funcionamento da visão dos sapos. Esta mostra como a Natureza otimiza o processamento de informações, amoldando as formas de vida correspondentes. As possibilidades de estudo do sistema visual do sapo são desafiadoras para a geração de novos produtos industriais. 
Com respeito ao tema central da pesquisa aqui apresentada, Dr. Frei Otto, da Universidade de Stuttgart, nos anos de 1960, pregava a necessidade de se observar mais as estruturas naturais a fim de se criar "uma nova arquitetura natural"14. E, se por um lado, Otto falava em termos de estruturas naturais aplicadas à forma da arquitetura, Matila Ghyka, D'Arcy Thompson e György Doczi nos ensinam a compreender, respectivamente, a "matemática da forma"15, como se dá o "crescimento na forma natural"16. Estes temas relativos às formas naturais sua estrutura, composição, textura tensão, resistência etc., têm chamado atenção de vários pesquisadores. Podemos destacar, por exemplo, os seguintes trabalhos: Carmelo di Bartolo, em 1981, apresentava pesquisa acerca das qualidades formais da Natureza17 para serem aplicados a modelos biônicos. Vítor Lotufo e seus colegas, nos anos 1980, prepararam um dos bons livros publicados no Brasil sobre estruturas geodésicas18. Por volta de 1985, um grupo de alunos comandados pelo professor Carmelo di Bartolo, apresentam a monografia Strutture Gotiche, Strutture Naturali19. No ano seguinte, Fabricio Vanden Broeck, resumiu em seu livro Las estruturas en ia naturaleza y en ia técnica20 as ideias seminais para a origem deste presente trabalho.

Para caracterizarmos com maior precisão os sistemas naturais nos quais queremos desenvolver este trabalho devemos retornar à classificação apresentada por Gui Bonsiepe21 que, em realidade, é uma confirmação de da classificação feita por Offner22. Conforme D. H. Offner, os sistemas existentes nos seres vivos podem ser classificados em: Sistemas de Transposição da Matéria; Sistemas de Transferência de Informação; Sistemas de Transferência de Controle de Movimentos; Sistemas de Transferência de Energia ${ }^{23}$.

No nosso caso o que nos interessa é identificar, observar, analisar e estudar, particularmente, os Sistemas de Transferência e Controle de Movimentos, uma vez que são os sistemas que nos podem dar a chave para a realização de nossos objetivos: aplicá-los a estruturas artificiais, ou seja, aquelas projetadas e desenhadas por seres humanos.

\section{PRIMEIRA PARTE}

\section{ESTRUTURAS DO REINO VEGETAL}

\section{Formação, flexão, fixação}

Entre os objetivos gerais desta pesquisa, destacava-se a observação de formas estruturais do reino vegetal tendo em mente os aspectos relativos à configuração, rigidez localizada, nervuras etc. Buscava-se, assim, compreender como resistem aos esforços a que são submetidos (e.g. tração, flexão, rotação) de forma única ou combinada. Sendo a forma combinada a mais frequente pois, por exemplo, num galho de uma árvore qualquer submetido ao vento os esforços de torção no galho não aparecem somente devido a um movimento rotacional deste em torno do seu eixo, mas de todos os movimentos que o vento o submeter. Também estamos atentos a outros exemplos, de estruturas que resistem ao corte e a fadiga. 0 que se tinha em vista, era encontrar estruturas que comportassem forças axiais, flexoras, torcionais, cisalhantes etc., de formas vegetais de possível mimetização industrial. 
Especificamente, os objetivos do trabalho eram os de dar continuidade ao processo de preparação de futuros docentes de projeto de produto no Centro de Tecnologia da UFSM, formando-os pesquisadores, professores e profissionais "para o próximo milênio. (...) O rápido avanço tecnológico no mundo, o importante papel do engenheiro e como este deve se preparar frente aos desenvolvimentos e desafios tecnológicos da atualidade são a nossa meta". Isto porque o Prof. Waldimir Longo, em palestra proferida em 3 de abril de 1996, em Aula Inaugural para os Estudantes do Centro de Tecnologia da UFSM"24 , fazia previsão de que dentro de 10 anos, os profissionais engenheiros hão de estar usando apenas 50\% dos conhecimentos adquiridos, hoje, em seus cursos de bacharelado. Justificavase, assim, o tema, pois, Biônica tinha a ver com a descoberta, mesmo que ilusória, de bases de autoaprendizagem projetual à invenção, à inovação tecnológica.

Focamos, principalmente, o nosso olhar para o reino vegetal que circunda o campus da UFSM, RS, a fim de reconhecer formas que pudessem ser associadas a peças de desenho projetual usados na engenharia mecânica. Criativamente, certos estávamos que tais saberes aplicados à Engenharia, proporcionariam aprimoramento nas disciplinas de projeto de produto já existentes, e, até mesmo, na orientação para a criação de novas disciplinas fundadas em metodologias da Biônica.

As possibilidades de se executar essas mudanças eram endossadas pelo Projeto REENGE, que estimulava, especialmente:

- O desenvolvimento e a aplicabilidade na Engenharia de novas técnicas capazes de proporcionar aprimoramento de disciplinas afins, já existentes, ou até mesmo a criação de outras novas.

- O aperfeiçoamento dos cursos de Engenharia na região centro-oeste do Rio Grande do Sul.

- 0 surgimento de profissionais engenheiros de Alta Criatividade (AC) 25 . Espera-se que como consequência tenhamos engenheiros mais criativos e com capacidade de integrar os seus projetos à Natureza, explorando-a adequadamente e de modo mais sustentável e renovável.

- O conjunto de procedimentos (táticas) e o grupo de habilidades (técnicas) para o desenvolvimento da pesquisa foi a escolha de: metódicas (ratio) gerais de projetação em Biônica; metodologias (via) específicas de pesquisas em Biônica; métodos (methodus) especiais de projeto de produto com base em Biônica ${ }^{26}$. Tais textos metodológicos foram de grande suporte ao andamento da pesquisa, mas também permitiram montar um cronograma para o desenrolar das atividades.

- O método adotado para projeto de desenho do produto foi essencialmente baseado naquele usado, em 1984/1985, por Luiz Vidal Gomes, no Curso de Desenho Industrial da UFPE ${ }^{27}$. As metodologias abraçadas como suporte para a orientação projetual foram aqueles descritas por Amilton Arruda (CDI/UFPE, 1991); Carlo Bombardelli (CREN/IED,1985); e David H Offner $(\mathrm{MED} / \mathrm{ITI}, 1974)^{28}$. As metódicas gerais de projetação, orientadas para Desenho Industrial, e sugeridas para os estudantes de Engenharia Mecânica, foram com base em textos de Victor Papanek (1977), Gui Bonsiepe (1978) e Fabricio 
Vanden Broeck (1986) ${ }^{29}$, primeiros professores a organizarem táticas e técnicas para o desenvolvimento de projeto de produto em Biônica.

O método adotado no projeto foi constituído de seis (6) Estágios macroestruturais (táticos) de desenvolvimento do projeto; e de três (3) Etapas midestruturais de criação projeto de produto - Preparação do Projeto; lluminação do Projeto; Elaboração do Projeto (tirocínicos) -; e mais nove (9) Fases microestruturais (técnicos) de desenho de projeto para a Apresentação do Produto. Destarte, melhor ajustávamos a pesquisa ao REENGE.

Quadro 1. Artifícios Metodológicos (3MMM) Projetos em Biônica

\begin{tabular}{|l|c|c|}
\hline \multicolumn{1}{|c|}{$\begin{array}{c}\text { Estágios macroestruturais } \\
\text { da projetação }\end{array}$} & $\begin{array}{c}\text { Etapas midestruturais } \\
\text { da criação }\end{array}$ & $\begin{array}{c}\text { Fases microestruturais } \\
\text { da desenhação }\end{array}$ \\
\hline $\begin{array}{l}\text { Estudo preliminar } \\
\text { (informar; orientar; fundamentar; } \\
\text { observar; associar) }\end{array}$ & $\begin{array}{c}\text { Identificação } \\
\text { Preparação } \\
\text { Compreensão }\end{array}$ & $\begin{array}{c}\text { Pesquisa bibliográfica } \\
\text { Revisão de literatura } \\
\text { Redação compilatória }\end{array}$ \\
\hline $\begin{array}{l}\text { Apresentação Limiar } \\
\text { (selecionar; afirmar; conceber; } \\
\text { autorizar) }\end{array}$ & $\begin{array}{l}\text { (Incubação } \\
\text { Esquentação } \\
\text { Comunicação Pós-liminar } \\
\text { (efetivar; precisar; qualificar; } \\
\text { equalizar) }\end{array}$ & $\begin{array}{c}\text { Técnica: Fotografia } \\
\text { Técnica: Calquegrafia }\end{array}$ \\
\hline
\end{tabular}

Objetivando não perder o fundamento e o foco, fez-se uso de várias referências metodológicas e estas serviram como guia à obtenção de resultados descritos nas seções dos relatórios, sintetizadas cada uma das etapas a seguir.

\section{IDENTIFICAÇÃO E PREPARAÇÃO DO PROJETO}

Reconhecimento de possíveis argumentos para o desenvolvimento da pesquisa que embasaria o projeto. Por argumento, compreendeu-se o raciocínio pelo qual se pode tirar deduções ou encontrar indícios que contribuem com o desenvolvimento de ideia para projeto. Nessa fase, portanto, procurou-se aprofundar sobre o tema através de livros, artigos, publicações especializadas etc. A adoção dessa tática favorecia utilização de tríade de técnicas em importantíssimas fases de qualquer pesquisa acadêmica, a saber:

Pesquisa Bibliográfica (PB), isto é, localização de livros e artigos que pudessem embasar a investigação.

Revisão de Literatura (RV), ou seja, apontar capítulos, seções, trechos de livros e textos que pudessem servir de frases centrais para a fundamentação do discurso projetual.

Redação Compilatória (RC), i.e., (id est), transcrição pelas mesmas letras (ipsis litteris) de frases centrais encontradas na $\mathrm{RL}$, permitindo, assim, melhor identificação do tema projetual, assim como o levantamento de questões-chave relacionadas às potencialidades de aplicação tecnológica do sistema natural focado no estudo e à exequibilidade à fabricação de produtos industriais. 
Uma vez identificado o argumento de pesquisa, procurou-se no reino vegetal delimitado algumas estruturas que fornecessem algumas respostas às indagações: Quais materiais caracterizam aquela estrutura? Que tipo de organização formal permite que se alcance tamanha função de resistência? Como funcionam as mutações estruturais ao longo do crescimento celular em tais fibras vegetais? Quando a estrutura passa informações de sobrecarga de esforço?

As respostas foram sendo formuladas à medida em que a observação da Natureza indicava estruturas vegetais que se adaptavam aos objetivos da pesquisa. Nesta fase, as estruturas vegetais observadas sofreram importante trabalho de documentação gráfica. A Fotografia (registro de sistemas vegetais pela luz natural ou artificial de microscópios) e a subsequente técnica de Calquegrafia (imitar servilmente, quase que copiando, a forma da estrutura (exo/ meso/endo) vegetal sobre papel manteiga) rumo à coleção de ilustrações de futuras consultas e iluminações para novos desenhos.

Por associação de ideias, aquelas estruturas que se aproximavam visualmente das ideias preliminares para o problema de investigação, foram selecionadas e avaliadas, utilizando-se técnicas de análise formal microscópica e análise macroscópica de suas propriedades funcionais e informacionais (resistência à tração, à torção, à compressão etc.).

Partiu-se, assim, das descobertas e dos resultados das técnicas analíticas realizadas para definição das estruturas vegetais que mais se encaixavam nos objetivos. Através de analogias entre o elemento vegetal estudado com os modelos imaginados, pode-se entender seu mecanismo de funcionamento chegando ao Projeto Biônico. Do projeto surgiu um modelo cujo objetivo não era ser necessariamente aplicado ao desenho de projetos de produtos industriais; mas, bionicamente falando, foi um "modelo biológico", seguindo um conceito de Victor Papanek. 0 modelo concebido ajudaria a verificar dados e informações de caráter biónico e compreender seus aspectos para futuras aplicações em projetos de desenho de produto.

Nesta última fase da pesquisa, procurou-se a unificação de textos curtos e associados às figuras para a elaboração do material que serviu de apresentação do trabalho em encontros de iniciação científica, sendo este modo o mais eficaz meio divulgação, pois o tema ainda era novo.

Destarte, por fim, expõem-se as contribuições obtidas utilizando a Biônica como metodologia de ensino:

- Estímulo aos estudantes de engenharia e de desenho industrial em matérias básicas, por exemplo, física, química, biologia, matemática, desenho etc.

- Despertar a Biônica como metodologia didática de longa aprendizagem, fosse para o desenvolvimento das capacidades intelectocriativas e das habilidades manuplasmativas.

- Aumentar o grau de consciência dos envolvidos com a prática projetual e qualidade da cultura material industrial, por exemplo, engenheiros, arquitetos, desenhadores Industriais. 
- Conscientização da responsabilidade destes profissionais na preservação ambiental e demonstrar que o questionamento sobre como se faz, como funciona, de que é feito, para que serve etc., é fundamental para que estudantes universitários - obrigatoriamente líderes culturais - ampliem seus conhecimentos adquiridos na graduação e, destarte, possam tornar os seus pensamentos produtivos mais divergentes daquilo que se encontra convergentemente estabelecido, seja na prática diária da graduação, seja nos caminhos da pós-graduação.

\section{SEGUNDA PARTE}

\section{ESTRUTURAS VEGETAIS SERVINDO DE IMPULSO À PROJETAÇÃO}

O princípio de desenvolvimento escolhido, como já citamos, é baseado nas didáticas sugeridas por Gomes, e Amilton Arruda, porém adaptada as nossas necessidades de acordo com o em três fases e implementada com uma quarta, para melhor ajustar-se ao projeto REENGE.

Onde no desenrolar desta primeira fase, Preparação do Projeto, procuramos coletar informações acerca do argumento de pesquisa a ser estudado, através de consultas de trabalhos como os de Fabrício Vanden Broeck, Gui Bonsiepe, Victor Amaral Lotufo, Norbert Wiener, Matila C. Ghyka, H. E. Huntley ${ }^{30}$, dentre outros presentes na Bibliografia.

E, através destas leituras, optamos por pesquisar sobre as estruturas naturais, quanto a sua forma, resistência à tração, compressão, flexão e torção; e sua composição.

Segundo o Aurélio (1975), define-se estrutura como a "disposição e a ordem das partes de um edifício, tendo também aplicação nos seres vivos, na Botânica, na Geologia, Física e Sociologia". Estrutura é uma palavra muitas vezes associada/ confundida com o termo "construção", mas, no entanto, esta trata do ato de dar estrutura à forma, função e informação de algo.

Para a Biologia, estrutura se refere a constituição anatômica e histológica. Na Física, a estrutura está presente onde existe material. Na Arquitetura, utiliza-se esse termo para expressar tudo aquilo que resiste a cargas. Por isso, percebeuse que "estrutura" - seja esta macroestrutural, mesoestrutural, microestrutral - está em tudo que nos rodeia, apresentando-se ora na forma, ora na função, ora na informação de algo que assegura um funcionamento cibernético.

Aqui, por "cibernético", compreende-se "o ato de levar um sistema de coisas ligadas entre si, a desenvolver um conjunto de operações automáticas para atingir um determinado fim" ${ }^{31}$. Quis-se, portanto, mostrar que o conhecimento e o emprego de estruturas, quando adequado, é de vital importância para a otimização qualitativa/quantitativa no desenvolvimento de projetos. Salientouse, assim, que, ao longo de sua história natural, as estruturas vegetais também vêm sofrendo mutações no intuito de se adaptar melhor ao meio-ambiente. Foram essas estruturas vegetais que serviram de impulso à criatividade neste projeto. 


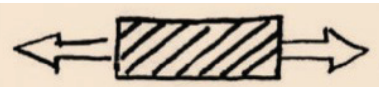

Figura 2a: tração

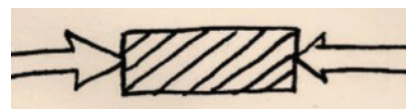

Figura 2b: Compressão

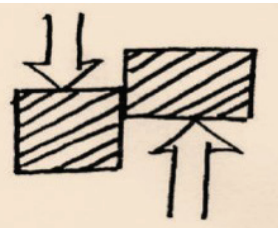

Figura 2c: Corte

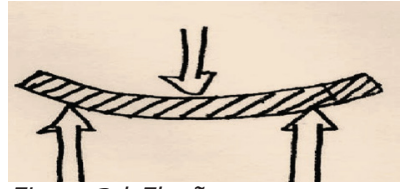

Figura 2d: Flexão

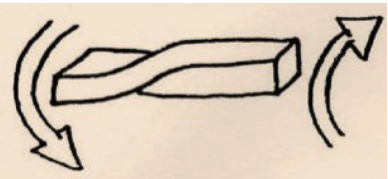

Figura 2e: Rotação

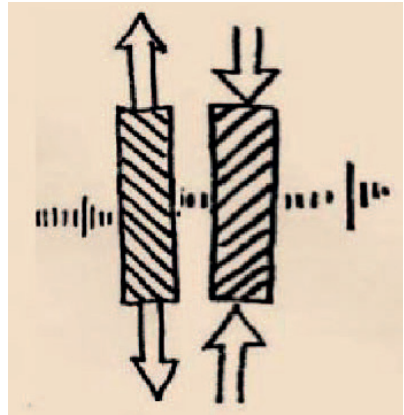

Figura 2f: Tensões/Deformação Diferentes tipos de cargas recebidas nas estruturas.

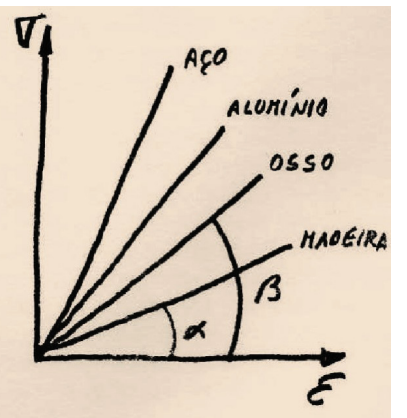

Figura 3 Gráfico das relações entre deformações (s $\sigma$ ) e esforço (ę) de distintos materiais.
Na definição de termos tínhamos a saber os seguintes:

- Carga: "Toda e qualquer ação que tende a alterar o estado de repouso ou movimento de um corpo". Cargas podem ser geradas por agentes externos ou por agentes internos (partes e componentes da estrutura) que se manifestam do seguinte modo:

- Tração (quando a estrutura sofre cargas dirigidas para fora). (Figura 2a)

- Compressão (quando a carga converge sobre a estrutura, tendendo a emplastá-la. (Figura 2b)

- Corte (quando cargas opostas atuam em planos paralelos, tendendo a deslocar as moléculas do material). (Figura 2c)

- Flexão (cargas opostas situadas em elos distintos, que tendem a causar um momento de flector sobre o corpo). (Figura 2d)

- Torção (cargas que tendem a deslocar as moléculas entre si segundo um determinado eixo de rotação). (Figura 2e)

- Tensão (esforço que atua em cada ponto da seção transversal. É definido por T = P/A, sendo $P$, carga aplicada; $A$, seção transversal. (Figura 2f)

Quando este esforço é de tração numa dada direção, provoca uma contração na seção lateral da peça. Este fenômeno é conhecido como efeito $d A$ relação entre as deformações em cada direção, nos fornece a constante chamada de coeficiente do Poisson, a saber:

$$
\mathrm{UU}=\mathrm{E} 2 / \mathrm{E} 1 .
$$

Sendo que E1 é a deformação na direção 1 e E2 a deformação na direção 2. Quando a carga é de compressão produz um efeito contrário.

Os tipos de cargas descritos anteriormente, geralmente, são encontrados na Natureza de modo combinado. Essas cargas provocam deformações nos corpos segundo a Lei de Hooke, a saber: A tensão (s $\sigma$ ) é proporcional ao esforço $\sigma=\varepsilon$. E (ę) multiplicado pela constante $\mathrm{E}$.

A constante E é o módulo de Young ou constante de Elasticidade. Para cada material há uma constante diferente como o indicado: (Figura 3)

No entanto, a Lei de Hooke é obedecida até um certo limite de tensão (Limite de Elasticidade), onde esforços maiores causam uma deformação plástica nos materiais (Deformação Permanente) até atingir a ruptura, como mostra o gráfico da Figura 4.

Os valores aproximados do módulo de Young, segundo J. E. Gordon32, definem o comportamento estrutural dos materiais. Estes também podem ser modificados com diferentes fatores, como: temperatura do ambiente; velocidade da carga; fenômenos de fluência; frequência de carga, que pode levar à ruptura por fadiga e concentração de esforços. 
Quadro 2. Tabela de valores do Módulo Young para alguns materiais

\begin{tabular}{|l|c|}
\hline Material & $\mathrm{E}\left(\mathrm{kg} / \mathrm{cm}^{2}\right)$ \\
\hline Membrana do osso & 82 \\
\hline Cartilagem humana & 245 \\
\hline Tendão humano & 6120 \\
\hline Polietileno & 14280 \\
\hline Madeira & 142800 \\
\hline Vidro comum & 714000 \\
\hline Alumínio & 714000 \\
\hline Bronze & 1224000 \\
\hline Ferro e aço & 2142000 \\
\hline Diamante & 12224000 \\
\hline
\end{tabular}

Por sua vez, a energia de deformação elástica é um tipo de energia definida como a capacidade de se realizar trabalho. Todo material elástico sob esforço, contém energia de deformação independentemente do tipo de esforço.

Os materiais que obedecem a Lei de Hooke, a energia de deformação elástica parte do zero quando o esforço é nulo, até um valor máximo que corresponde ao limite de elasticidade do material. Segundo J. E. Gordon, a energia de deformação

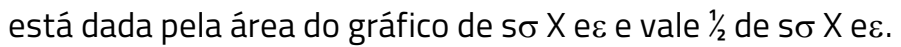

Na Figura 5, temos a demonstração de uma forma de absorção de energia; e na Figura 6, representação gráfica da energia de deformação elástica e nela se demostra o gráfico definidor da área corresponde a Energia de deformação de alguns materiais.

Outro aspecto a ser observado e a resiliência, ou seja, a capacidade de um material armazenar Energia de Deformação. Pode também ser definida como: A quantidade de energia de deformação que um material pode armazenar sem sofrer deformações irreversíveis. A deformabilidade de um material e a pouca rigidez, conferem a um corpo a resistência ao impacto. Do ponto de vista da resiliência a natureza tem uma grande vantagem sobre o homem que já dispõe de diversos tecidos biológicos com propriedades elásticas notáveis.

Um pequeno exemplo é a teia de aranha, que está exposta a impactos quando um inseto se choca contra a teia; a energia de impacto é absorvida pelos fios da teia. $O$ interessante da teia de aranha é que os fios radiais que formam parte da estrutura, são três vezes mais fortes que os fios curtos dispostos em círculo. (Figura 7)

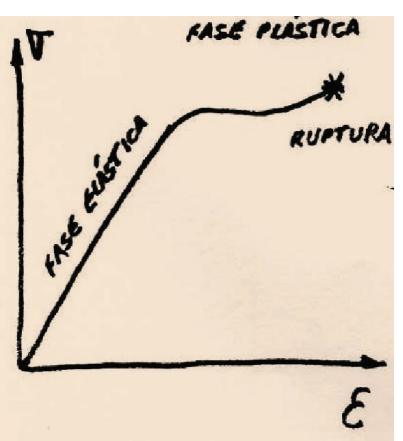

Figura 4: Gráfico demonstrando a fase plástica do material e ponto possivel de ruptura.

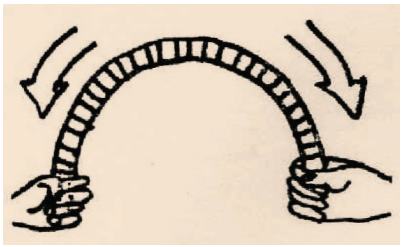

Figura 5.

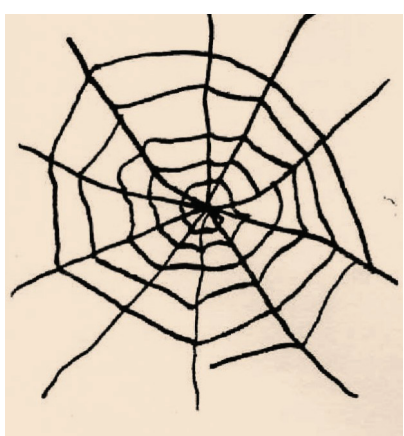

Figura 6

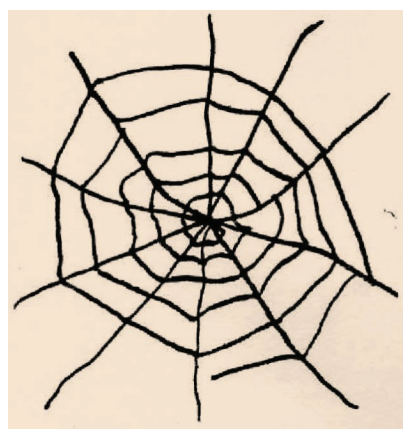

Figura 7: Disposição geral dos fios de uma teia de aranha. 


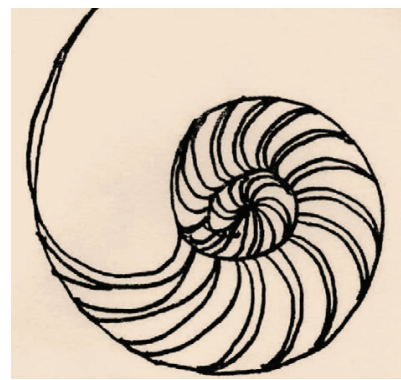

Figura 8: Radiografia da concha de um Náutilo de Câmaras (Náulilus Pompiluis), uma concha marinha moderna. As sucessivas câmaras do Náutilo estão construídas sobre a estrutura de uma espiral logarítmica. A medida que a concha cresce, 0 tamanho das câmaras aumenta, mas seu formato permanece inalterado (veja H. E. Huntley, p. 3). Exemplo do crescimento de um organismo mantendo a sua analogia de tensão superficial inicial.

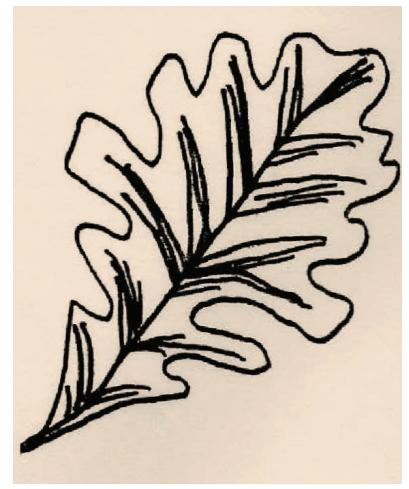

Figura 9: Exemplo de como a natureza otimiza as estruturas para que os organismos tenham uma determinada forma com o mínimo de material.
Ressalta-se também que as estruturas naturais sofrem com o efeito de escala, pois parte da evolução das formas na natureza pode ser explicada pelo efeito de escala, devido a qual a evolução das formas é também uma evolução de tamanhos.

As primeiras formas de vida consistiam em amebas e outros organismos unicelulares cujas diferenças substanciais eram pequenas. Nesses organismos, a estrutura protetora consistia em uma membrana formada pela tensão superficial das substâncias orgânicas. A escala de tensão superficial tem a resistência suficiente para dar coesão ao organismo. À medida que foram aparecendo outras formas de vida de dimensões maiores, a membrana foi endurecendo e diferenciando-se, primeiro mantendo uma analogia da tensão superficial em termos de elasticidade, como podemos constatar em muitos moluscos. Logo, o progressivo endurecimento gerou o exoesqueleto de crustáceos, insetos e outros animais. (Figura 8)

Com os tamanhos superiores foram aparecendo novas soluções qualitativas, que combina uma estrutura rígida e uma membrana externa em tensão, citando o caso dos mamíferos.

Também com o passar do tempo como já citamos, novas soluções estruturais para aumentar o tamanho dos organismos sem aumentar seu peso e assim diminuir sua quantidade de material foram surgindo. As plantas necessitam de grandes áreas para absorver energia do sol e assim poder realizar a fotossíntese. Para garantir a sua rapidez necessária, pequenos caules lançam-se sobre as folhas com um mínimo de material. Todas estas informações coletadas em revisões literárias e na observação da natureza como um todo, levaram-nos a escolher o estudo das estruturas dos vegetais como argumento de pesquisa, onde então a partir de agora passamos a observar os vegetais de forma mais qualitativa e se possível quantitativa no que tange a sua composição, forma e resistência. (Para maiores informações e definições sobre resistência dos mate riais e estruturas naturais, veja W. A. Nash e Fabrício Vanden Broek). (Figura 9)

\section{TERCEIRA PARTE}

\section{MOVIMENTOS E ELEMENTOS DE SIMETRIA}

Neste momento, o "argumento de pesquisa" já é conhecido. Assim, começouse a procurar fontes de informação a respeito das estruturas vegetais, suas formas, organização, inflorescência, nomes científicos, composição etc. A primeira investigação foi realizada na Biblioteca Central da Universidade Federal de Santa Maria, RS. Nesse recinto, percebeu-se a carência de material para estudo sistemático de determinados vegetais que apresentam características interessantes para aplicação em projetos de produtos, criativamente, orientados pela Biônica. Por exemplo, pouco encontramos sobre o Bambu ${ }^{33}$, o Capim Santa Fé e o Capim Anoni, vegetais estes encontrados facilmente na região de Santa Maria, Rio Grande do Sul.

Então para os primeiros estudos utilizamos livros sobre Botânica Sistemática, vistos que eram abundantes em nossa biblioteca, tais como o de Alfreda William Thames $^{34}$. Com este livro analisamos plantas, como a samambaia e a margarida, 
para termos mais noções sobre processos conhecidos por inflorescência. Em paralelo, procuramos desenvolver analogia com a folha de coqueiro e, em especial, o bambu, elemento vegetal que nos interessava, a princípio.

As análises preliminares da samambaia forma visuais. E, por mais simplista que pudesse ser, pudemos observar que a samambaia possui, quando observada em um plano, simetria bilateral, como se houvesse havido a reflexão de um dos lados no outro. Porém, uma observação mais detalhada mostra que, de fato, a análise é mais complicada, pois, ocorre que a samambaia não é simétrica, mas, sim, assimétrica, pois combina um movimento de rotação, logo gerando uma simetria axial.

Comparativamente, por exemplo, com a palha de coqueiro, há ligeiras diferenças entre os movimentos: a folha do coqueiro, de imediato, parece ter sido refletida quando se traça um eixo pelo seu caule. Já a folha de samambaia (Caliandra do serrado) apresenta um pequeno deslocamento entre os seus lados, caso se trace o eixo no caule de sustentação das pequenas folhas. Estas também, apresentam um fenômeno simétrico: a cingenometria (de cingere, "apertar" em italiano), ou seja, pequenas deformações projetivas, mas afins. Tanto o coqueiro como a samambaia, apresentam "simetria bilateral", característica de quase todos os seres vivos, pois favorece o crescimento deslocamento e rápidos. (Figura 10)

As folhas, com forma irregular, assemelham-se a uma cerra, e a sua estrutura como um todo tem grande flexibilidade, possuindo uma forma parecida com a de uma coluna vertebral. As samambaias, botanicamente, são vegetais da divisão dos Embriófitos, Assifonógamos, Subdivisão dos Pteridófitos.

A samambaia é uma planta sem flores e provida de raízes e vasos para a circulação da seiva. Segundo Thames (1977), as samambaias, plantas que pertencem à família das Polipodiáceas, são da divisão Embriófitas Assisfomógamos, Criptógamos Vasculares, possuindo determinadas características, tais como:

- Aparelho esporífero na página dorsal da froude ou das pinas.

- Pecíolo sem ramificação ou falta.

A flor margarida ${ }^{35}$, por sua vez, possui crescimento radial, formando uma flor simétrica, com pétalas que se sobrepõem e sendo bastante flexível. É uma planta da divisão dos Embriófitos Sifonógamos; subdivisão das Angiospermas; classe das dicotiledôneas e possuindo algumas características como:

Possuir flores Andrógenas; (2) Dois, quatro ou cinco estames; (3) Tubo de corola é, em geral, inteiro ou falta; (4) Flores em capítulo ou glomérulos; (5) Anteras Conatas; (6) Estiletes bífido no ápice. É uma planta que pertence a família dos Sinantéreos, segundo Thames (1977). Veja a Figura 11.

Para se compreender melhor os elementos formadores de uma planta, algumas palavras relativas às plantas precisaram ser melhor denotadas, como, por exemplo: angiospermas (possuem óvulos dentro de um ovário); giminospermas (não possuem frutos); cotilédone (equivale a face, uma metade); dicotilédone (duas metades); estames: parte masculina da flor; inflorescência (a união de várias flores e o modo pelo qual se apresentam).

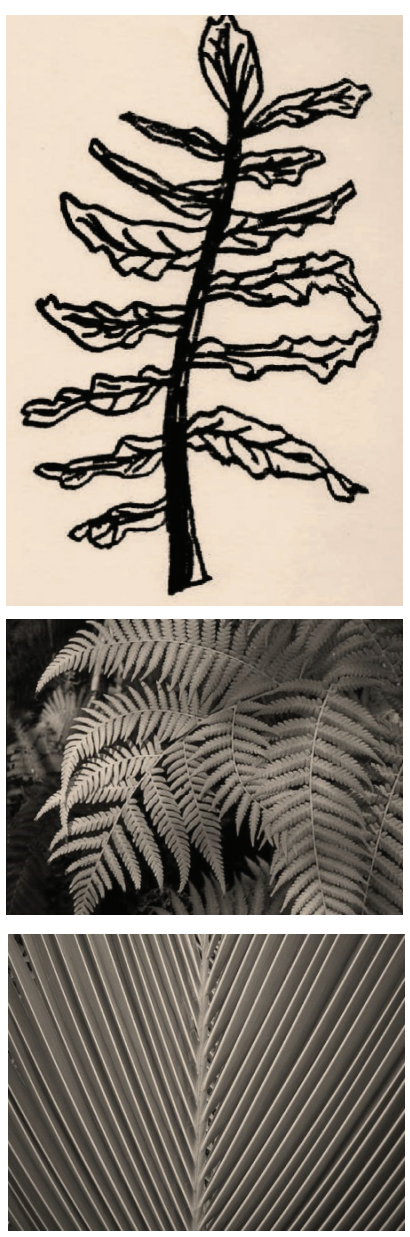

Figura 10: Detalhe de crescimento e da simetria entre a folha de samambaia e coqueiro.

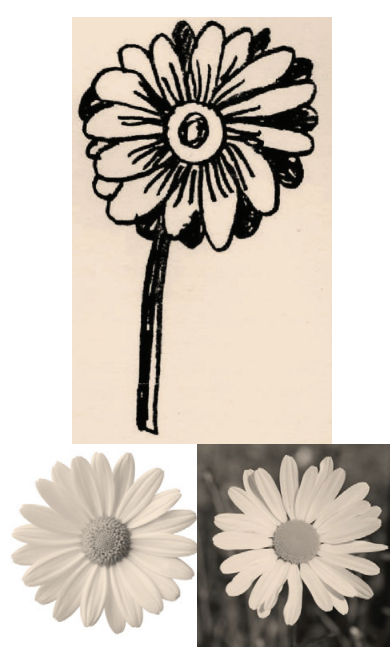

Figura 11: Detalhe de crescimento e da simetria de margaridas. 


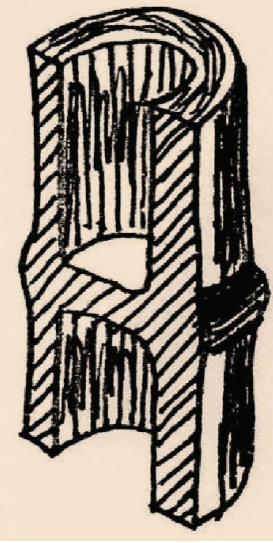

Figura 12: Corte transversal dado a um dos nós do bambu.

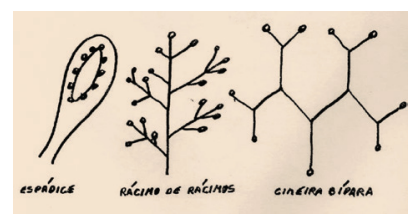

Figura 13: Tipos de Inflorescências.

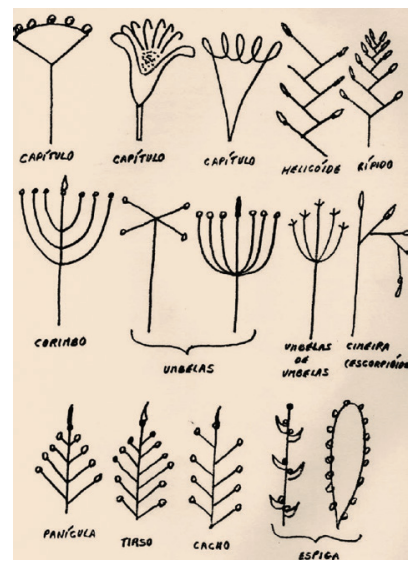

Figura 14: Tipos de inflorescência.

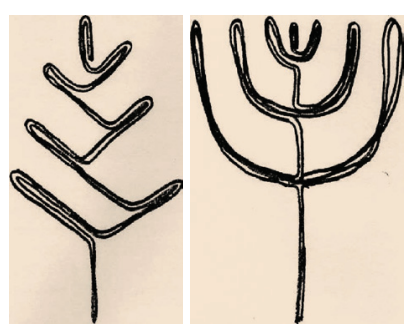

Figura 15: Modelos feitos de arame pera análise de suas caracteristicas de forma física. (a) corrido; (b) rápido.
A planta seguinte a ser analisada visualmente foi o bambu. Trata-se de uma estrutura tubular resistente, possuindo fibras alongadas à olho nu (Figura 12), e é adequada a esforços fletores multidirecionais. Apresenta seção circular com um centro oco e nós distribuídos progressivamente ao longo de seu comprimento, o que the dá uma característica peculiar em relação a maioria dos vegetais.

\section{TIPOS DE INFLORESCÊNCIA}

Ainda segundo Thames ${ }^{36}$, os tipos de inflorescência são os mostrados de modo esquemático nas Figuras 13 e 14, ajudam-nos a identificar, em primeira instância, quais os tipos de estruturas vegetais que possuem maior resistência para os diferentes tipos de esforços, levando em conta apenas a forma.

Com isto, não levando em conta a composição e resistência do material constituinte da planta, com um pouco de imaginação desenvolvemos uma técnica simples de reproduzir os diferentes tipos de inflorescências, a modelagem com arame. (Figura 13)

Por utilizar o mesmo material, arame, para todos os modelos, permite distinguir quais os mais resistentes e adequados para os diferentes tipos de aplicação, bem como quais os pontos críticos de cada um. (Figura 14)

Dois exemplos de estudos deste método são destacados na Figura 15, com a comparação dos pontos críticos de cada uma e as vantagens e desvantagens de cada uma para determinadas aplicações. Primeiro, caracteriza-se por grande flexibilidade nas direções paralela e perpendicular a seu eixo central, enquanto o segundo é mais rígido, caracterizando-se pela distribuição das deflexões a todas as partes, "galhos", de forma proporcional e isso faz com que o mesmo realize grande amortecimento do esforço realizado sobre ele na direção paralela ao eixo principal do modelo do arame. (Figura 15)

\section{Exemplos de algumas inflorescências}

As Figuras 16 e 17 trazem dois exemplos de vegetais que apresentam determinadas Inflorescências, sendo o primeiro uma ciperácea com a inflorescência do tipo umbela e o segundo, um bambu do tipo espiga. As figuras ilustram como e o que são as inflorescências.

\section{Colênquima, parênquima e esquerênquima}

Nesta fase da pesquisa, quando ainda estávamos à procura de materiais e pessoas que pudessem nos ajudar, conhecemos a professora Jumaida Maria Rosito, da Biologia, Setor de Botânica, que não poupou esforços em nos ajudar, fornecendo bibliografias, filmes e laboratório para auxílio a pesquisa. Com isso tivemos acesso a livros como o de Elizabeth G, Cutter ${ }^{31}$ o qual nos possibilitou um maior estudo das partes e constituintes dos vegetais. Outra pessoa foi Adelino Alvarez, professor aposentado da Biologia da UFSM, que indicou algumas plantas das quais poderiam possuir as características que procurávamos, como resistência e facilidade de encontrar na região, tal como o capim, o bambu, e um dos vegetais estudados, a ciperácea. 


\section{Colênquima}

O colênquima (Figura 18), tecido de sustentação, trata-se de conjunto de células extensiveis com considerável grau de plasticidade e funcionam como tecido de suporte nos órgãos em crescimento. Possuem protoplastos e paredes celulósicas espessas. Geralmente, ocupam uma posição periférica nos órgãos em que aparecem e podem aparecer na forma de faixas discretas.

\section{Parênquima}

É o tecido fundamental das plantas, encontradas na medula e no córtex dos caules e das raízes etc. Com paredes delgadas, vacuolizadas e com protoplastos vivos. Podem ter paredes secundárias de lignina como no xilema secundário. O parênquima é afetado pela pressão e tensão superficial, na qual estas forças afetam a forma do tecido, moldando-o na forma de um poliédrico, com média de 14 facetas, como mostra a Figura 19.

\section{Parênquima nas plantas aquáticas}

Especial interesse tem o parênquima de plantas aquáticas e da nervura central da cana, que possuem a mesma característica, com espaços intercelulares (vazios), sendo assim alongados num plano, ou com braços ou ramos (como nas células dos tecidos paliçádicos). Elas possuem esta forma devi do ao estiramento mecânico durante a fase de crescimento. Veja Figura 19. Nas plantas aquáticas, o parênquima é conhecido como aerênquima:

"Antigamente acreditava-se que este tecido com abundante espaços aéreos funcionava somente na aeração e fornecendo poder de flutuação às plantas aquáticas; mais recentemente, tem sido apontado que tal sistema é caracterizado por uma resistência excepcional por uma quantidade mínima de tecido e tem sido sugerido que o sistema de espaços intercelulares em forma de favo de mel poderia ser uma maneira eficiente de resistir ao considerável estresse mecânico a que podem estar submetidas as plantas num ambiente aquático".37 (CUTTER, 1986)

\section{Esquerênquima}

As paredes celulares são paredes secundárias espessas e as células geralmente não têm protoplastos vivos quando maduras. Apresenta função semelhante ao colênquima, porém não tem conteúdo vivo e é lignificado. Pode ser dividido em esclerócitos e fibras, tendo as fibras especial atenção devido sua grande utilização económica.

São alongadas com extremidades pontiagudas e podem aparecer sozinhas ou em feixes. São conjuntos de feixes que constituem as fibras duras (sisal) ou fibras macias como o linho, são principalmente fibras de linho. As fibras produzidas pelas plantas têm sido aproveitadas economicamente há muitos séculos. Existem evidências de que o algodão foi usado entre 7.200 a 5.200 a.C., em Tenhuacam, Vale do México, entretanto, o algodão é obtido a partir dos pelos da testa da semente e não é uma fibra verdadeira no sentido botânico.

Aproximadamente 1.000 anos atrás, o povo do deserto de Utah, nos Estados Unidos, sabia como extrair as fibras vegetais, talvez pela mastigação de parte das plantas e como moldá-las numa corda; cordames de vários tipos têm sido encontrados nas cavernas a níveis que datam de 9.201 a.C. Uma bolsa completa

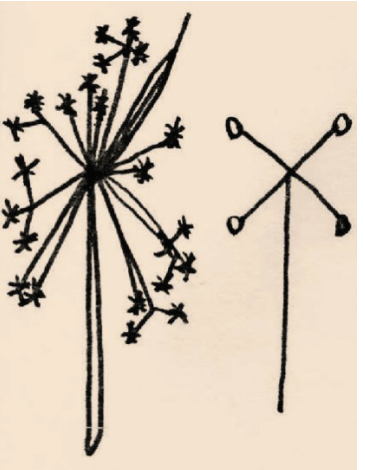

Figura 16: Cyperus Baspan. SSP Juacóides.

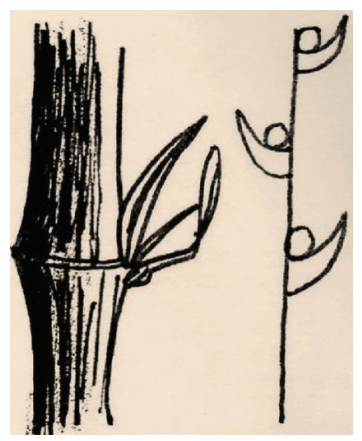

Figura 17: Bambu inflorescência tipo Espiga inflorescência tipo Umbrela.

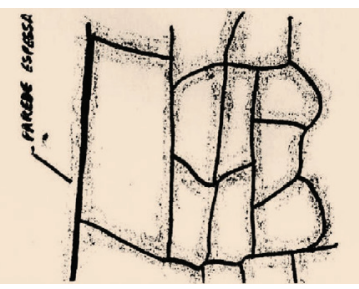

Figura 18: Amostras do colênquima.

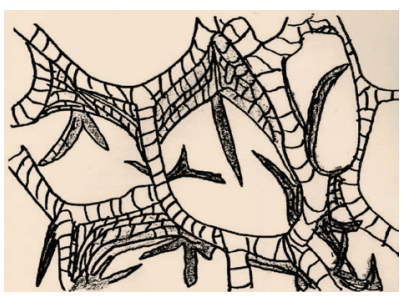

Figura 19: Micrografia eletrônica mostrando os Astroesclerócitos ramificados nos espaços aéreos colunares, que pode ser uma maneira de aumentar a resistência do pecúlo. 


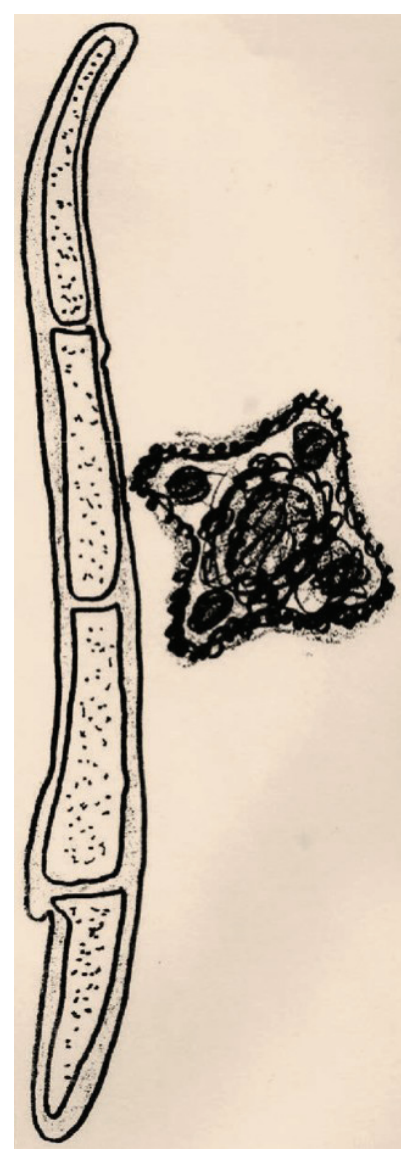

Figura 20: Cortes longitudinal e transversal da fibra da videira. de barbante ou rede feita de fibras entrelaçadas de Apocymum tem sido datada de, aproximadamente, 5.000 a.C. Existe evidência de que o linho e o cânhamo têm sido cultivado para obtenção de fibra há 4.000 ou 5.000 a.C. As fibras de "Salvadora persica", um arbusto prostrado da península do Sinai, são usadas pelos beduínos com escova de dente. Pedaços do caule com a casca removida de uma extremidade são colocados numa pedra até o fim e desfiado em projeções como cerdas. As cerdas constituem de grupos de fibras xilemáticas

Hoje, plantas de quarenta e quatro famílias diferentes são usadas como fonte de fibra. As fibras comerciais comuns podem ser divididas em fibras têxteis, incluindo o linho (Linum usitatissinum), juta (Corchorus sp.), cânhamo (Cannabis), rami (Boehmeria nivia) e fibras de acordeamento incluindo o sisal (Agave sisalana), o cânhamo da África (Sansevieria sp.) e cânhamo da Nova Zelândia (Phormium tenax).

\section{Análise da fibra da videira}

Devido a toda esta importância da fibra, realizamos uma análise formal e de características da fibra, procurando reproduzi-las através de modelos, como mostra a Figura 20 e suas sucessivas seções.

A Figura 21 é uma figura geométrica baseada na fibra da videira. Com cilindros maciços apresentando cavidades esféricas onde esferas são acopladas. Na Figura 22 encontra-se destacado o cilindro maciço que apresenta cavidades esféricas em sua extremidade.

A seguir, observamos o mesmo elemento da Figura 23, porém envolvido por uma mola helicoidal que possa proporcionar maior flexibilidade ao modelo biônico. Aqui, apresentam-se as caraterísticas necessárias para que o modelo possa ser flexionado e no momento da liberação de carga, possa retornar à curvatura inicial. A Figura 24 mostra a esfera que serve como elemento de articulação e junção ao imaginado "joelho".

A Figura 21 apresenta uma bifurcação em Y que poderia ser configurada em outras letras para utilização como gancho ou ligação para novas ramificações estruturais. Têm, por base ou fonte de inspiração, as saliências existentes nas figuras naturais estudadas. A Figura 22 exibe modelo com extremidade cônica, sendo uma pontiaguda e outra cônica, indicando base de apoio. Esta base é inspirada na saliência natural que as fibras apresentam. Observem-se os detalhes da base.

A Figura 23 apresenta um modelo com de uma canalização ocorrendo simultaneamente. Aqui, as mangas que contraem a base cônica-esférica, encontram-se apenas nas junções para que seja possivel um sistema que uma as barras laterais. Estas barras laterais podem ser distribuídas de acordo com o lado onde seja solicitado os maiores esforços. Na base observa-se um dos tipos de ligações entre os tubos que podem existir.

No detalhe da Figura 23 ainda pode-se sugerir dois distintos modos de união entre os tubos. Essas ligações poderiam ser feitas, através de uma vista da 

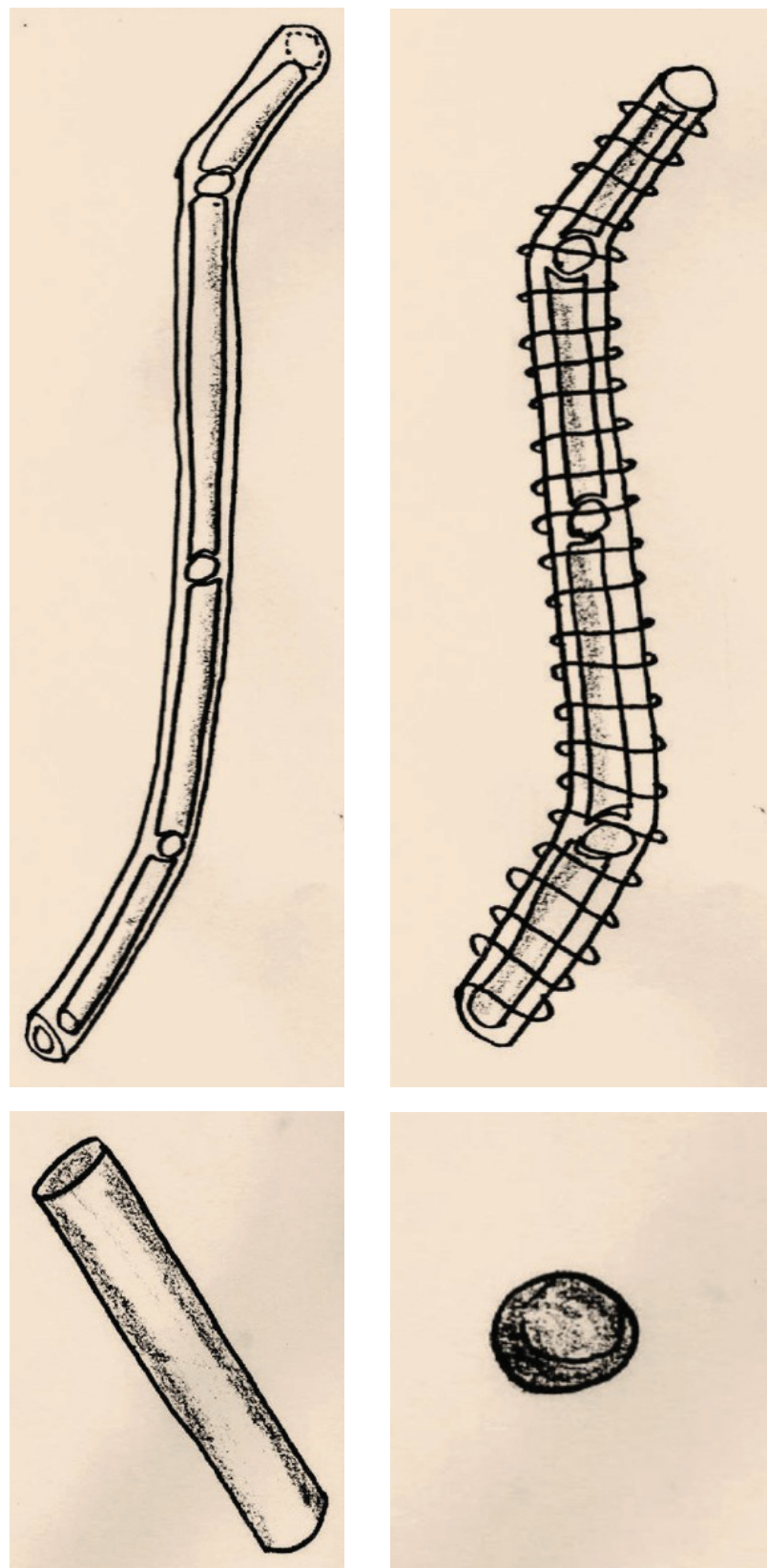

Figura 21: Corte de possivel modelo para a estrutura da videira. Detalhe do cilindro externo.

Figura 22: Modelo, a partir da estrutura da videira, mola em hélice para flexibilidadel resiliência.
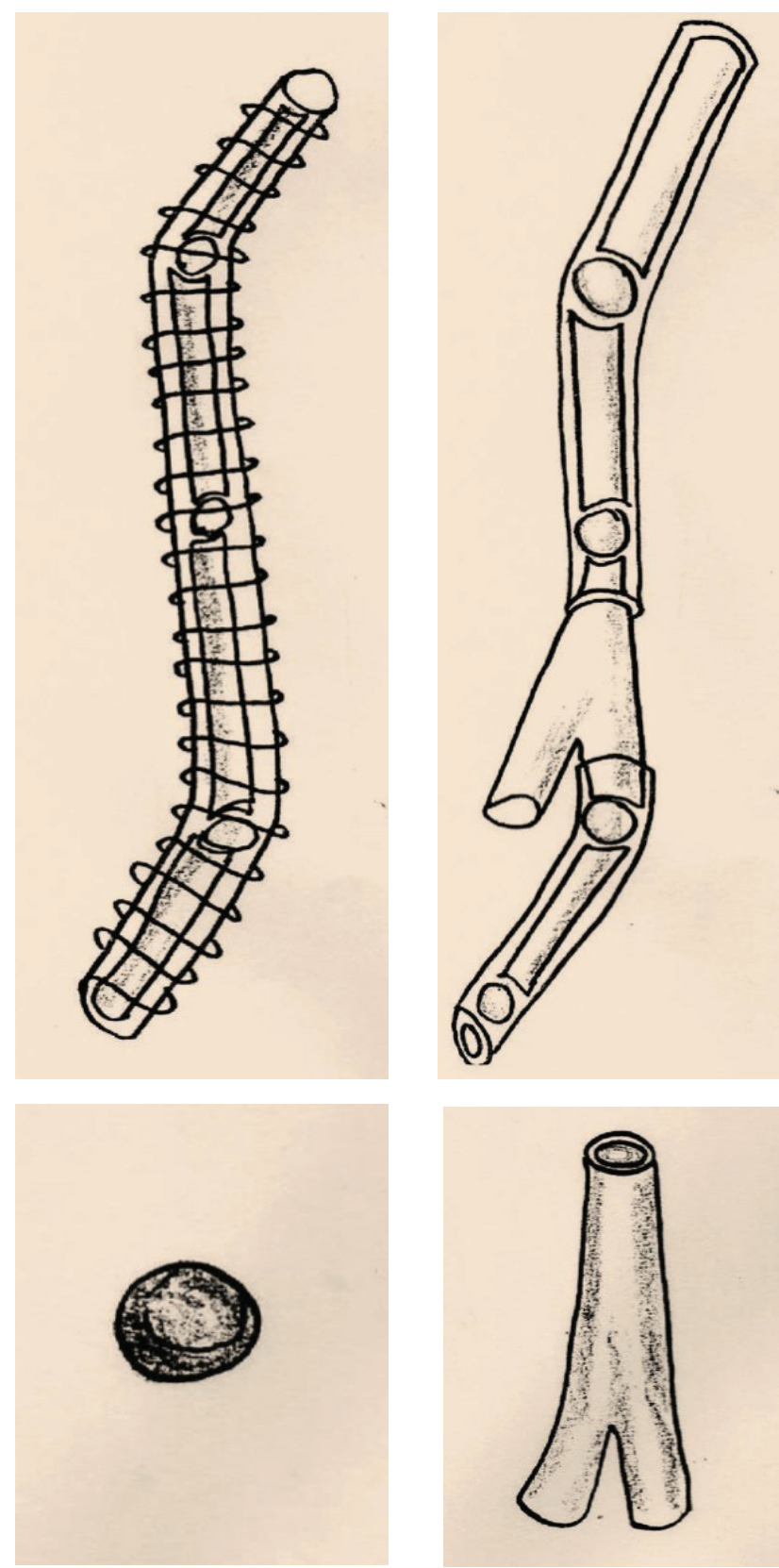

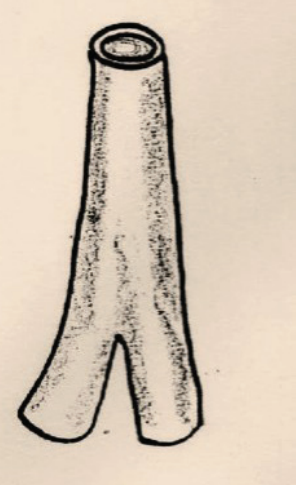

Figura 23: Modelo, a partir da estrutura da videira, com extremidade bifurcada em $Y$ invertido.
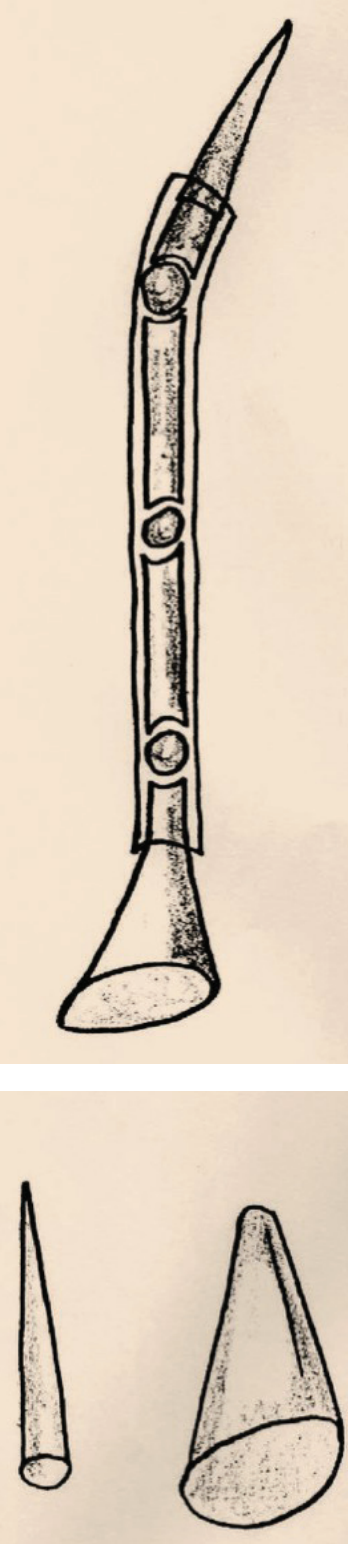

Figura 24: Modelo, a partir da estrutura da videira, com extremidades cônicas.

planta do modelo, enquanto que a Figura 24 mostra o detalhe das conexões, que não tem o mesmo comprimento dos tubos, pois se tivessem o mesmo comprimento atrapalhariam o bom encaixe das junções ao curvar todo o conjunto. Porém, os canais de fixação das peças de ligação existentes nos tubos são de fora a fora para facilitar a montagem e permitir que as mesmas se desloquem ao longo dos canais ao flexionar-se o conjunto. 


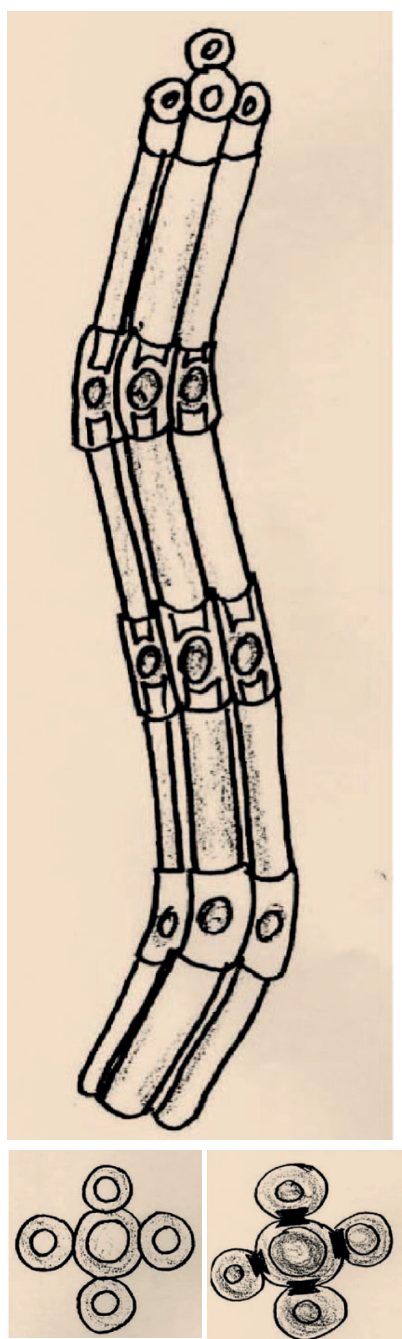

Figura 25: Modelo composto com vários elementos baseados nas fibras da videira. Possiveis vistas transversais da junção dos modelos.

Figuras 26 e 27: Possiveis modos de junção de tubos e articulações entre esses mesmos conduteis. Detalhe de como as ligações conjuntos de ligações em Y. poderiam ser realizadas.
A Figura 25 é semelhante a anterior, porém mostrando um feixe de tubos acoplados para aumentar a resistência do modelo.

\section{Análise do caule da videira}

No laboratório do departamento de Biologia, Setor de Botânica da UFSM, RS, realizamos a análise do caule da videira do tipo Vitaceal, Vitisvinífera com a orientação da Professora Vera Siqueira e da Técnica de laboratório Elcy Batistella obtendo dados importantes da estrutura organizacional da planta e de sua constituição.

Observamos que esta planta não possui um único sistema ou tipo de célula que Ihe atribui resistência, mas um conjunto de fatores que desempenham funções específicas a sobrevivência da planta, que somados, dão resistência a mesma.

A Figura 26 exibe, em perspectiva, a forma com que o vegetal se apresentou na análise microscópica, onde a partir deste especificaremos as funções de cada componente. Começando de fora para dentro, temos uma espécie de casca da planta, ou tecido de revestimento (Epiderme) que é responsável pelas trocas gasosas do vegetal com o meio ambiente em que ela vive. (Detalhe 1 da Figura 26).

Também visualizamos a forma irregular do caule, tendo saliências dirigidas para várias direções, de acordo com o esforço solicitado naquele ponto. Essas saliências, (Detalhe 2 da Figura 27), são compostas basicamente de células colenquimáticas, que aparecem em grande quantidade principalmente na fase de crescimento da planta.

Como já vimos, ela dá resistência a planta e lhe permita ter flexibilidade. Estas células colenquimáticas, aparecem como principal elemento de sustentação
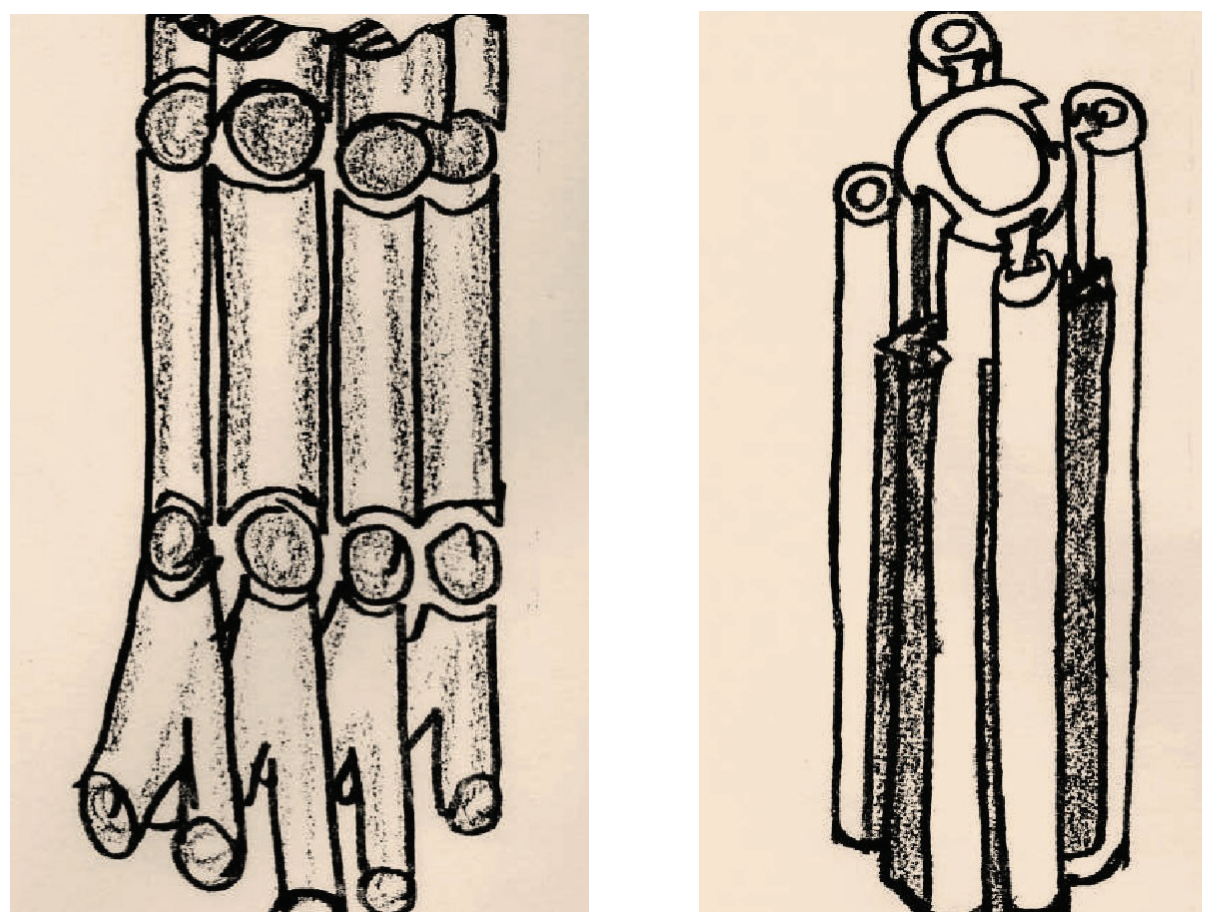
quando a planta é jovem e na videira é do tipo lacunar, onde apresentam espaços intercelulares e espaçamentos de parede junto a eles. (Detalhe 3 da Figura 28), que mostra o espaçamento maior da parede celular do colênquima nos pontos de interseção das células. Na parte central do caule, temos a medula, detalhe 4, que é parenquimática e tem por função armazenar substâncias, como o amido. Em muitas espécies a medula é um espaço vazio, não sendo preenchida com células parenquimáticas como na videira.

Na videira, quem executa o transporte da seiva bruta e água, é o xilema (detalhe 5) que é composta por três tipos de células: a) Células condutoras (detalhe 6); b) Células de sustentação, que são as fibras (detalhe 7); c) Células de transformação, que são parenquimáticas (detalhe 8).

As células de sustentação ou fibras, são alongadas e como já vimos, são também responsáveis pela resistência mecânica dos vegetais, sendo compostas de lignina. Geralmente, aparecem em feixes entre as células condutoras do xilema como mostra a Figura 34.

Segundo Elizabeth Cutter (1986), o feixe de células fibriformes é composto por uma camada de parede primária e três camadas de parede secundária de celulose, e espaços intercelulares entre elas. As células menores do xilema são chamadas de Protoxilemas, e as maiores são chamadas de Metaxilema.

As grandes estão bem lignificadas devido a fase de diferenciação e possuem a seguinte característica: Apresentam pontuações na parede celular devido a forma como a lignina se deposita. Estas pontuações podem ser regulares ou regulares como na videira, assemelhando-se a uma mola ou rugas na parede celular, como mostra a Figura 30, isto é, células que conduzem a seiva, o xilema.

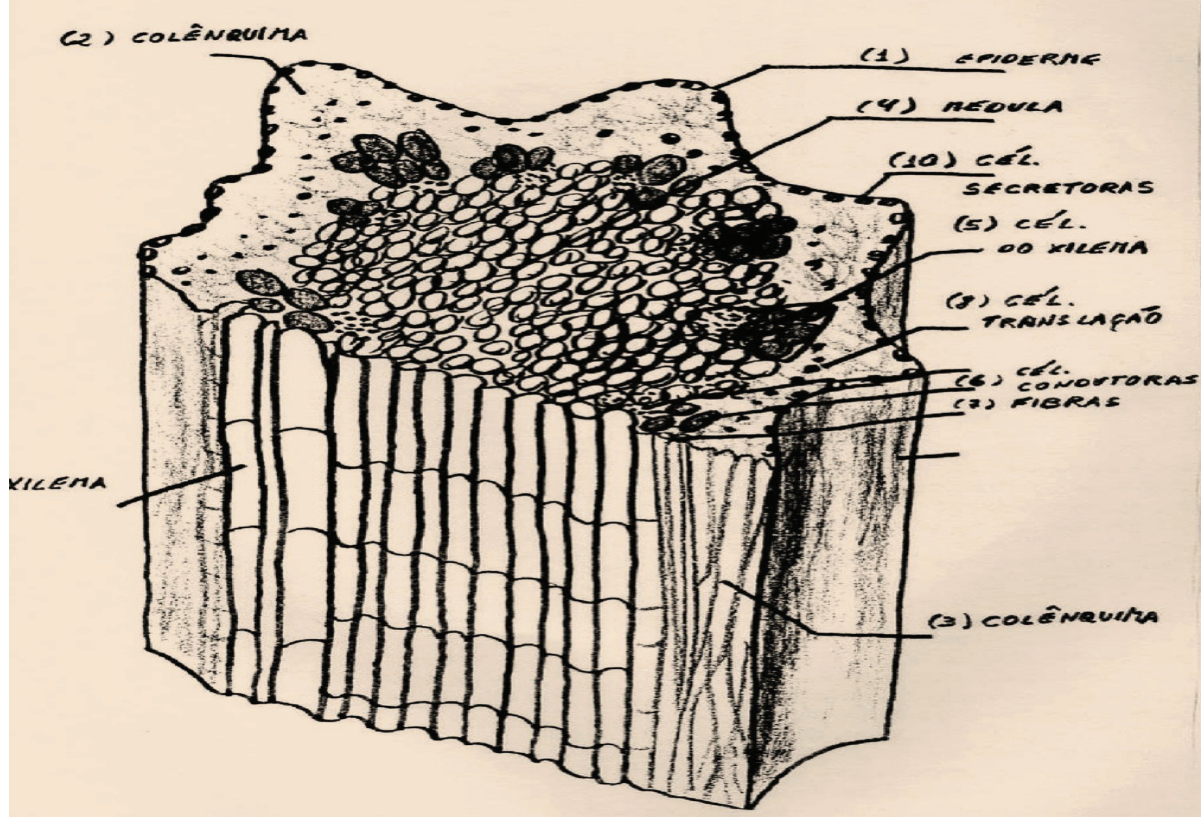

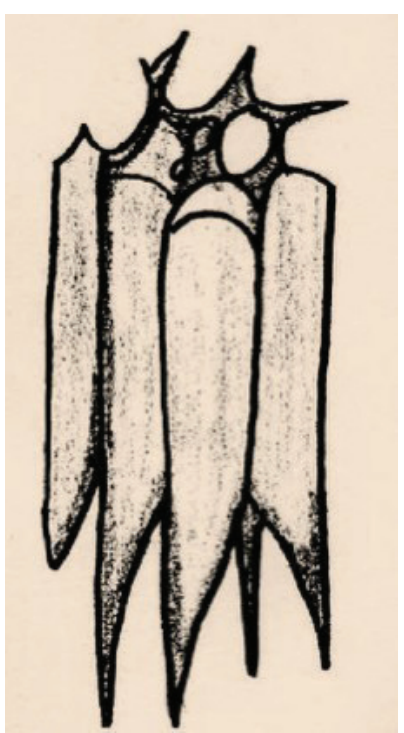

Figura 28: Destaque do colênquima, que possui parede celular mais espessa nos cantos das células.
Figura 29: Desenho em perspectiva do caule da videira observado ao microscópio em Laboratório da UFSM, RS, para análise endoestrutural. 


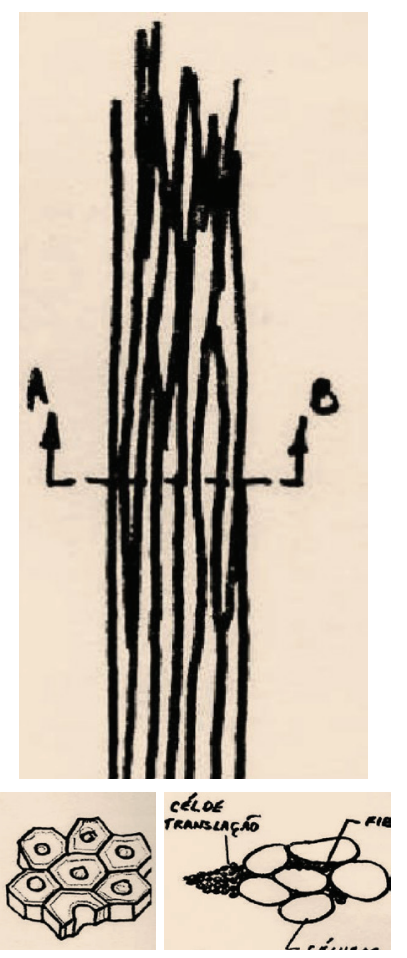

Figura 30: Xilema com suas células compositoras. Forma estrutural da fibra emo feixe.
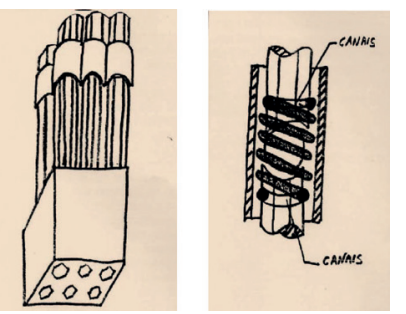

Figura 31: Destaque do colênquima, que possui parede celular mais espessa nos cantos das células.

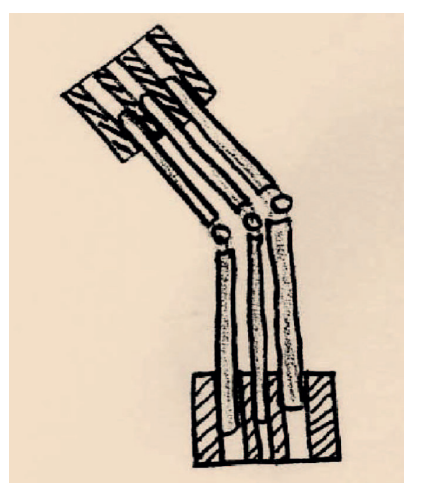

Figura 32: Deslocamento das peças sextavadas dentro dos cubos.
Já as células condutoras de seiva elaborada, floema, são células fobriformes, como as fibras de sustentação do xilema, apresentando a mesma forma alongada (detalhe 9 da Figura 33), com a diferença de conduzirem nutrientes resultantes da fotossíntese. Por último (detalhe 10 da Figura 29), temos as células secretoras encontradas de forma dispersa no caule.

\section{A análise de um argumento biônico}

Como vimos, o interesse pelo estudo da videira é o fato de ela possuir uma flexibilidade e uma característica interessante de poder curvar-se em torno de objetos para melhor crescer e fixar-se exposta ao sol. Um dos componentes mais interessantes na sua constituição é a fibra do xilema, com excelente flexibilidade e resistência, a partir de uma análise qualitativa. Elas são alongadas e encontradas em feixes, podendo ser ceptadas ou não, como mostra a Figura 31 (amostra de uma fibra ceptada) e outro não. Esta característica é função da forma como a lignina se distribui na fibra. Baseado nesta concepção e nos estudos realizados em laboratório, podemos fazer analogias da geometria da fibra anteriormente esboçada nas Figuras 23 a 35 em forma de um pré-modelo biônico: como motivador para o debuxo de novos modelos inspirado nos estudos analíticos do modelo da videira.

\section{Análise e síntese de modelo biônico}

O esquema da Figura 32 mostra um sistema montado em peças de seção sextavada, semelhante às fibras, tendo cubos distribuídos ao longo do seu comprimento, como forma de fixar as peças de seção sextavada em feixes. Para unir cada uma dessas peças, são utilizadas juntas que possibilitam curvar o feixe. Essas juntas poderiam ser associadas a esferas envolvidas por uma mola helicoidal que se fixa a cada uma das peças sextavadas por meio de canais, como ilustrado na Figura 33. Esse sistema possibilitaria também, que o feixe retornasse à posição inicial devido a energia de deformação armazenada na mola.

Deve-se citar, também, que as peças sextavadas possuem o comprimento desejável, começando na junta esférica e terminando na metade dos cubos, aproximadamente. Isto possibilitaria que a peça fosse curvada, sem se desfazer o sistema, como mostra a Figura 34.

Uma peça sextavada corre mais que outra dentro do cubo, de forma a compensar a dist6ancia percorrida pelas externas às curvas que possuem um raio de curvatura maior. Os feixes de peças podem ainda ser agrupados, formando um círculo de feixes, assumindo assim uma semelhança ainda maior com a disposição das fibras no caule da videira, como mostram as Figuras 32 e 33. Esta disposição pode ser regulada e simetricamente como o demonstrado, ou assimétrica, na qual os feixes estariam colocados nas regiões de maior esforço.

Observando ainda as mesmas figuras percebemos que elas nos trazem muitas imagens criativas, oferecendo constantes iluminações, estalidos mentais, impulsos projetuais, como, por exemplo, o uso da parte direita do nosso cérebro, os espaços entre as raias de ligação dos feixes poderiam passar algo como tubulações de construção hidráulica, semelhante aos condutos de seiva de plantas. (Figura 34) 
Ou imaginando de outra forma, este círculo de feixes poderia assumir uma forma helicoidal ao combinarmos um conjunto deles, como aquela em que o caule da videira (gavinha) assume ao enroscar-se em um tronco, ilustrado na comparação entre as Figuras 35 e 36.

Este tipo de disposição traria adaptabilidade a estrutura a qualquer tipo de irregularidade que se encontrasse no local onde se dispõem.

\section{Análise estrutural dos vegetais em geral}

Nesta fase do projeto, quando estávamos já analisando a estrutura de vegetais específicos, não deixamos de procurar locais e pessoas que pudessem contribuir com o trabalho, foi quando então entramos em contato com o Professor Nilton Marquiori, do Curso de Zootecnia da UFSM, que não dispensou esforços em contribuir com nossa pesquisa, fornecendo material e orientação ad hoc em estruturas vegetais.

Devido a orientação do Prof. Marquiori, chegamos a conclusão de que a forma mais adequada para a análise das estruturas vegetais era dividindo-as em três níveis a saber: 1. Análise ultramicroscópica; 2. Análise microscópica; 3. Análise Macroscópica.

A análise ultramicroscópica trata-se de estudo em microscópio eletrônico, desenvolvido no início do século, sendo o mais elucidativo por fornecer um nível tão detalhado que pode ser entendido como a fronteira com a composição química da estrutura analisada.

As células vegetais em geral, apresentam a composição química de celulose, hemicelulose, lignina e extrativos.

A celulose é o principal constituinte das células, sendo um polímero de forma aproximadamente esférica, com cerca de 5 Ângriston (Um, 1, Ângriston vale a $1 \times 10^{-9}$ mícron) de diâmetro. É composto de Bglicose, isto é, (C6H10015), 6 átomos Carbonos, 10 átomos Hidrogênios e 15 átomos de Oxigênio, possuindo uma quantia de aproximadamente $6 \times 10.000$ unidades, ou seja, (C6H10015)n onde $n=6.000$. Cada uma destas moléculas de Bglicose tende a ligar à outra, formando uma cadeia. Veja a Figura 38.

A maior importância desta molécula é o fato de ser polarizada $\left(\mathrm{CO}_{-} \mathrm{H}_{+}\right)$, possibilitando nada mais que a existência do mundo. Além de tudo, as moléculas tendem a ligar-se a outras por pontes de hidrogênio, formando uma complexidade ainda maior que as moléculas de celulose, as microfibrilas, que são feixes formados por milhares de moléculas de celulose. Veja as Figuras 39 e 40.

Na Figura 39, as microfibrilas aparecem duas zonas bem definidas: 1. Zona Cristalina (Micelas), bem semelhantes a cristais; 2. Zona Amórfica, que é a região em que ocorre as pontes de hidrogênio. Ela explica o fenômeno hidrogeno da madeira (absorção de água).

Das microfibrilas em diante, a Bglicose forma novas estruturas ao combinaremse novamente, na sequência: 1 . Molécula de celulose; 2 . Microfibrilas - Feixe de milhares de moléculas de celulose; 3 . Macrofibrilas - Centenas de microfibrilas; 4. Lamelas - Camada que liga duas células com centenas de Macrofibrilas, tendo característica curiosa, que é a lamela média não possuir celulose; 5. Parede Celular.

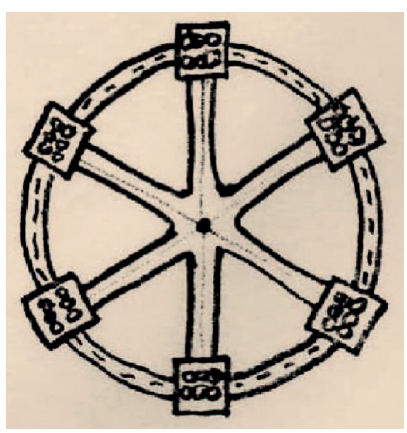

Figura 33: Disposição circular de um feixe baseada na disposição da videira

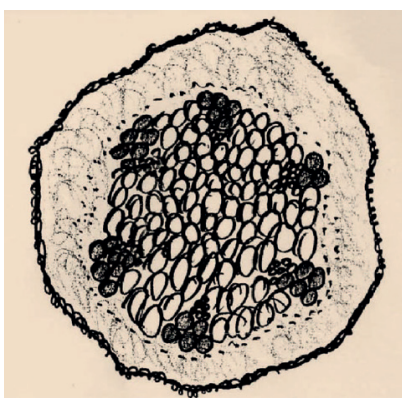

Figura 34: Círculo de feixes com tubulações internas de condução.

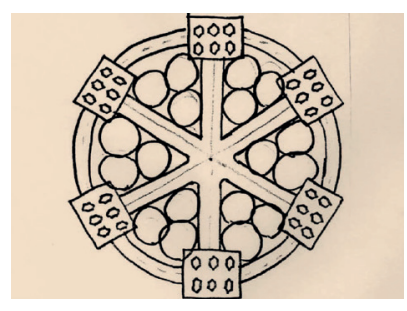

Figura 35: Círculo de feixes em forma helicoidal, como no caule da videira.

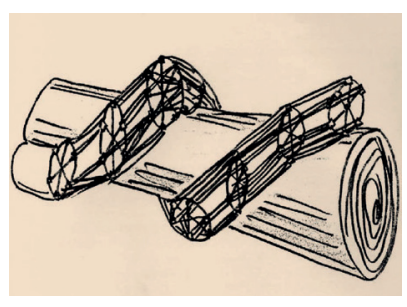

Figura 36: Círculo de Feixes em forma helicoidal, como no caule da videira. 


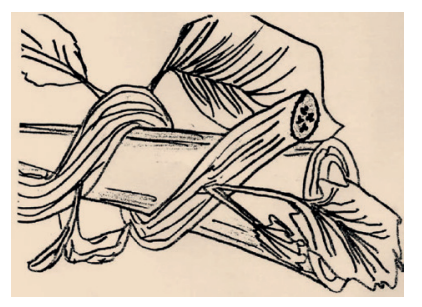

Figura 37: Caule da videira (gavinha) enrolada em um tronco.

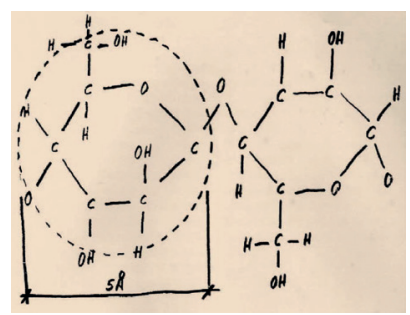

Figura 38: Ligação de duas moléculas de Bglicose, base da formação da celulose.

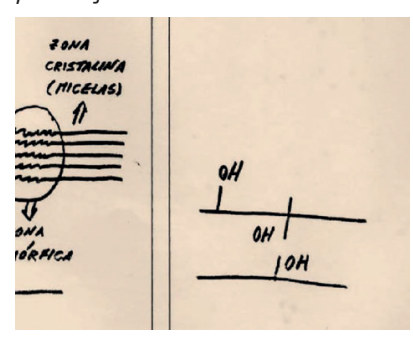

Figura 39. Pontes de hidrogênio; partes da microfibrilas e o local das pontes de hidrogênio.

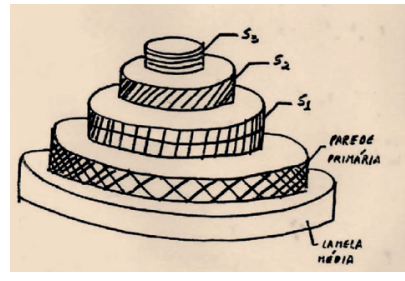

Figura 40: "Bolo em camadas", mostrando a organização dos feixes de moléculas nas camadas da parede celular.

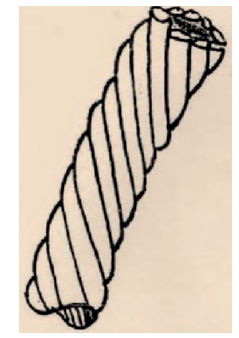

Figura 41: Detalhe de um cabo de aço.
Todos estes elementos citados formam a parede celular das células ou melhor, cada uma das paredes. Os sentidos de progressão dentro de cada parede são diferentes, e isto faz com que os elementos fiquem cruzados, aumentando a resistência da parede celular, com um mínimo de material. A Figura 40 ilustra estas paredes com cortes realizados na parede celular, formando algo parecido com um bolo em camadas.

A estrutura resultante assemelha-se a um cabo de aço, com seus fios de aço entrelaçados sobre um arame mais grosso central. Esse arame central seria o interior da célula e os fios a parede. Veja a Figura 41.

No entanto, as células são encontradas em grandes quantidades, e uma exercendo pressão sobre a parede das outras, fazendo com que sua forma seja semelhante a de um polígono qualquer, como é mostrado na Figura 42, para uma forma sextavada.

A hemicelulose também conhecidas como meio-celulose, não possuem composição química definida, pois é composta de muitas substâncias em quantidades aleatórias, como glicose. Ela é o constituinte que preenche as células, tal como a argamassa o é na construção civil (enchimento). Caracterizase por ser higroscópica e por isso é facilmente removível com água quente quando analisada em laboratório. É quebradiça e pode ligar-se com outras moléculas polares.

A lignina é uma substância aromática tridimensional, altamente estável, mais estável que a própria celulose, pois é composta por álcoois que são mais fortes que as pontes de hidrogênio da celulose. Ao contrário da hemicelulose, a celulose não pode ser quebrada, pois é mais estável. A lignina é uma cadeia de álcoois conifenílicos e álcoois simafíbicos obtidos pela hidrogenação da Fenilalamina (formada pelo radical Benzênico que progressivamente transforma-se em Ácido Cinânico e Cirívico, devido a perda de Amônia, e sucessivamente em Álcoois Conifenílicos e Simafíbicos, como ilustra a Figura 43.

Por extrativos, consideram-se todos os elementos que se encontram infiltrados na célula. É graças aos extrativos, a lignina, a hemicelulose e a celulose que as células apresentam uma extraordinária resistência, sendo que até hoje o homem não conseguiu criar um material tão resistente quanto a célula, em relação a seu peso.

0 radical benzeno é formado por seis átomos de carbono e também seis hidrogênios ligados à carbonos, distribuídos segundo uma simetria, como a mostrada na Figura 44 deduzida pela difração de nêutrons. Nela estão claramente visíveis o anel de benzeno com curvas fechadas, linhas de contorno, que identificam a densidade dos elétrons e sua distribuição simétrica.

As análises micrográficas permitiram que observações da anatomia das plantas fossem feitas, formalmente, que para entendê-las iremos classificar as células em dois tipos, que segundo nomenclatura contemporânea são: 1. Prosenquimáticas; 2. Parenquimáticas. 3. As células Prosenquimáticas, caracterizam-se por apresentar a parede celular espessa, muito lignificada, atuando na condução da seiva bruta. Elas atuam também na sustentação 
mecânica da planta e são células normalmente mortas. Como exemplos deste tipo de célula, temos as: Traqueídeas; Elementos vasculares; Fibras, Fibrotraqueídeas e fibrolibriformes.

As células parenquimáticas são vivas por mais tempo que as anteriores, possuindo uma parede fina para facilitar a troca de substâncias com o exterior, e são pouco lignificadas. Elas atuam no armazenamento de substâncias de reserva da planta. Como exemplos desta classificação temos, o parênquima radial e o axial.

A anatomia da madeira, as plantas podem ainda ser divididas em Angiospermas e Gimnospermas. As Angiospermas ainda podem ser divididas em Dicotiledôneas e Monocotiledôneas, sendo que as Gimnospermas e as Dicotiledôneas possuem tronco. Já as Monocotiledôneas não possuem tronco, ou seja, não possuem câmbio, apresentando como outra característica a presença de estipe e colme.

O câmbio é a parte morta de uma árvore (cerne), sendo composta, principalmente, de células prosenquimaticas e por isso é o que dá resistência ao tronco da árvore. Este por sua vez, é envolvido pelo alburno, que possui algumas células vivas. (Figura 45)

Pelo citado, concluímos que todo tronco de uma árvore é morto, sendo que a única parte viva é a casca, também mostra a medula, parte da planta que é viva somente quando jovem, onde servirá como armazenamento de substâncias. Este tipo de informação pode ser obtido com uma análise a olho nu (Macroscópica), porém para uma melhor sequência a citamos agora.

\section{Exemplo da anatomia de uma angiosperma dlcotiledónea}

Como exemplo, temos a videira que já havíamos citado, e que por isso não entraremos em grandes detalhes, destacando, no entanto, os corantes utilizados, que são:

1. Safranma: Que colore de vermelho a lignina, e, portanto, as células prosenquimaticas.

2. Azul de astra: Que colore as células parenquimáticas. Coloração obtida na micrografia em seus elementos constituintes, aparecendo também as células radiais, conhecidas como raias, que fazem a condução da seiva elaborada da casca para as células vivas do alburno.

Exemplo da anatomia de uma angiosperma monocotiledónea: As plantas analisadas foram o coqueiro e o bambu, que como já foi visto, caracterizam-se por não apresentar raias e câmbio; e sem feixes libero lenhosos (Líber Floema; Lenho Xilema) dispersos simetricamente na matriz.

Nela, o floema é composto de células parenquimáticas, assim como em todas as plantas, e os elementos vasculares e fibras com células colenquimáticas.

No entanto, o que se observa no caso do bambu é uma concentração dos feixes libero lenhosos na parte externa do caule, tornando-o extremamente resistente

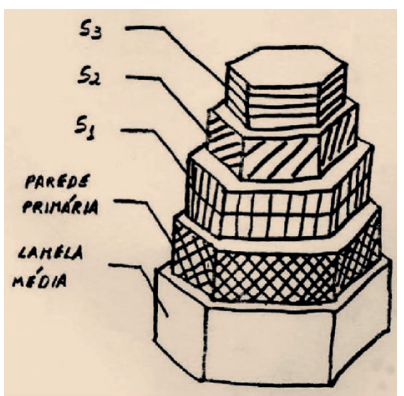

Figura 42: Forma como se apresenta a célula no conjunto, com destaque para as camadas da parede celular.

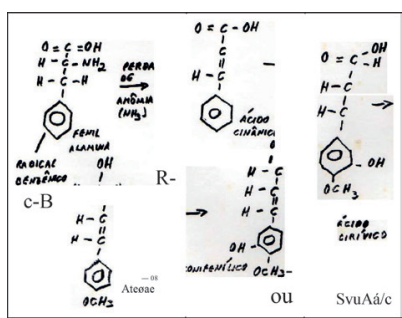

Figura 43: Hidrogenação que ocorre para obtenção da Lignina que é composta de álcool conifenílico e sinafíbico.

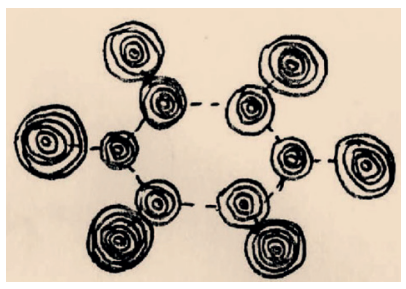

Figura 44: Difração de nêutrons mostrando a simetria do Benzeno.

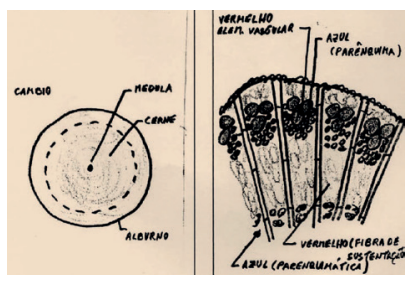

Figura 45: Tronco de uma árvore. Corte do caule da videira, sem a casca; destacando a coloração obtida com os corantes. 


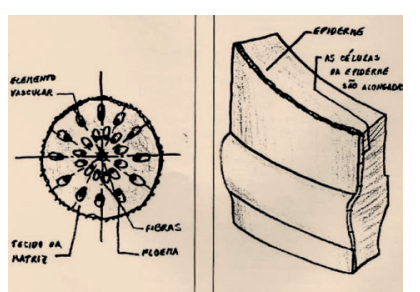

Figura 46. Corte transversal de uma Angiosperma Monocotiledônea (coqueiro); Destaque para a epiderme do bambu.

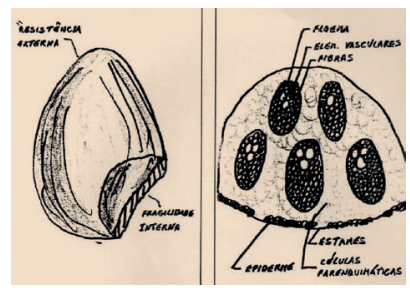

Figura 47: Corte casca de ovo; detalhe dos estames dispostos na epiderme.

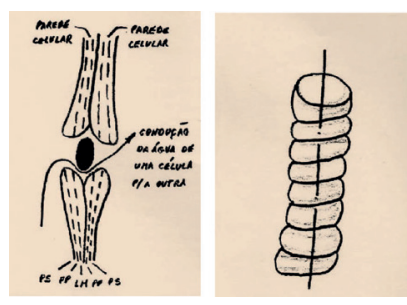

Figura 48: Pontuação nas paredes de duas células; Placas de perfuração em parede celular.

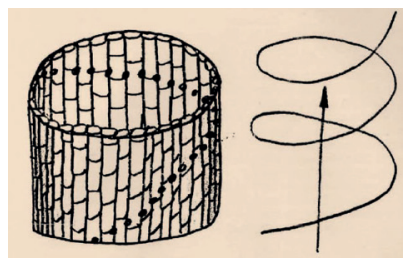

Figura 49: Desenho esquemático mostrando como se processa a condução da seiva nas plantas, tanto bruta quanto elaborada. por fora, ou seja, o bambu é mais forte externamente do que se aplicarmos esforços de dentro para fora. Este fato, é semelhante ao que ocorre com a casca de um ovo, que resiste a esforços grandes externamente, como o peso de uma galinha para chocar o ovo, bem como é tão frágil internamente, que o bico do pintinho possa quebra-lo. (Figura 46)

Outro fator que dá resistência externa ao bambu bem como dureza e impermeabilidade, é a cutina, que forma a cutícula na epiderme, possuindo estómatos que permite a troca de material com meio, como mostra a Figura 47.

E numa escala macroscópica, o fato de o bambu ser oco e possuir entre nós, ou seja, estrutura tubular, possui excelente resistência a esforços flexores multidirecionais. (Figura 48)

\section{Pontuações: placa de perfuração e comparação com filotaxia vegetal}

Pontuações são ligações entre as paredes celulares, como se fossem portas abertas que permitem a passagem de água de uma célula para a outra, como demostra a Figura 49. As plantas de perfuração são semelhantes as pontuações no que tange a sua função, porém tem a aparência de uma superfície enrugada, ou de uma mola em espiral. (Figura 50)

E é interessante destacar que estas ligações das paredes celulares ocorrem de forma radial de uma célula para a outra, fazendo com que a seiva conduzida na planta descreva uma trajetória em espiral, ao ser conduzida até o topo da planta, no caso de condução da seiva bruta. A Figura 48 ilustra este processo exercido na condução da seiva, a qual não foi identificada a razão para isso, nas supõemse ser devido a potência necessária para bombear as substâncias (água + seiva) de pequenos níveis de altura de forma sucessiva, seja menor do que a potência necessária para bombear do chão diretamente para o topo da árvore.

Outra possível razão, é o armazenamento da seiva ao longo de todo o comprimento da árvore. Vale aproveitarmos a oportunidade, e compararmos este fenômeno com a filotaxia, que é o termo usado na botânica para um tópico que inclui a disposição das folhas nos ramos das plantas, na qual as disposições são características dos gêneros. Divergência das folhas é o termo técnico empregado para descrever a separação angular das bases de suas folhas consecutivas no talo, medida através de uma espiral traçada da raiz da planta para o ponto de crescimento. (Figura 50)

Traça-se uma espiral que passa pela base de cada folha até atingir a primeira base verticalmente acima do ponto de partida. Tomando " $p$ " como o número de voltas da espiral e q como o número de bases de folhas pela qual a espiral passou, excluindo a primeira, então p/q é uma fração característica da planta. (Veja, por exemplo, HUNTLEY, H. A divina proporção. Brasília: Editora UnB, 1985, p. 157-159).

0 interessante desta relação, é que para todas as plantas ela se situa entre 1/2 e $1 / 3$, de modo que as sucessivas plantas estão separadas uma das outras por ao menos 1/3 da circunferência do talo, assegurando o máximo de iluminação e ar para a base do talo. Segundo H. E Licks, como regra geral, as divergências nas várias plantas podem ser dispostas como seguem: Gramíneas comuns 1/2; Ciperáceas 1/3; Frutíferas, como a macieira 2/5; Tanchagens 3/8; Libáceas 5/13. 


\section{Análise macrográfica}

A macrografia é o estudo ou análise da planta a olho nu, e com ela podemos observar as seguintes características: A madeira, caule, é composta de medula, madeira propriamente dita e a casca. A Figura 51 mostra as disposições destas partes no caule, e nela também podemos identificar outros elementos, como o câmbio vascular (limite da madeira com a casca), que é onde se produz as células para a casca e para a madeira, e com põem-se apenas de uma camada de células, com somente parede primária, para facilitar a troca de material. Podemos identificar quando termina o crescimento de uma célula, pois se obtêm a parede secundária (camada de força), determinando a vida da célula que segue:

- divisão;

- crescimento;

- parede secundária;

- lignificação (mais resistente);

- morte.

Isto tudo é identificado porque a madeira (xilema) é quem conduz a seiva bruta, e caracteriza-se por ser morta. Já a casca (floema), é composta de células vivas e conduz a seiva elaborada.

Com isto, podemos concluir que a videira estudada anteriormente era uma planta jovem, pois ainda não apresentava a madeira entre a medula e os condutores de seiva elaborada, floema. Outra conclusão a que se chega, é que se a casca de uma árvore for removida, ela está condenada à morte, pois não há como mandar seiva elaborada para a raiz da árvore, que morrerá à míngua, e, assim, deixará de mandar seiva bruta para o ápice da árvore, matando-a por completo.

Fazendo uma observação mais apurada do corte transversal do tronco da árvore, ainda podemos identificar a sua Idade, contando o número de círculos claros ou escuros concêntricos no caule, sendo a parte clara a fase de maior crescimento da planta, que ocorre na primavera; e a parte escura de menor crescimento, no Inverno.

Na mesma figura, ainda podemos observar linhas radiais identificando as células com sentido radial, e as transversais, concêntricas, que indicam a disposição da maioria das células.

As células transversais executam todas as funções vistas até agora, e as radiais tem uma peculiaridade, que são ser células vivas que servem de condução da seiva elaborada para aquelas células que ainda se encontram vivas dentro da madeira, pois num tempo passado, estas células que ainda se encontram vivas faziam parte da casca (parte sempre viva) antes da árvore crescer radialmente.

Também é interessante a observação de que a medida que a árvore fica velha, seu crescimento radial diminui, aproximando as linhas escuras (inverno) das linhas claras (primavera). 0 fenômeno da madeira trincar com o passar do tempo, depois de morta a árvore e cortada, também pode ser entendida macroscopicamente, que é devido à hidrogenação da planta (água), que quando morta evapora a água, fazendo com que ocorra uma contração das células sem vida.

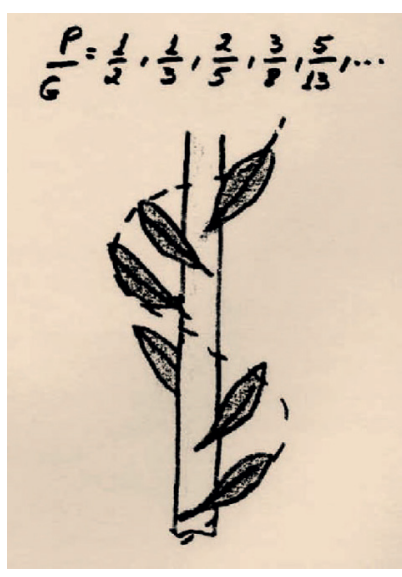

Figura 50: Filotaxia das plantas.

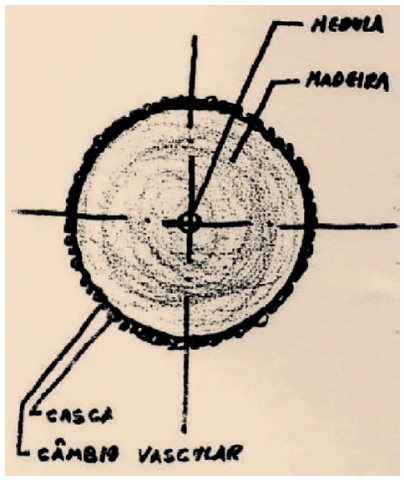

Figura 51: Corte do tronco de uma árvore mostrando a madeira e a casca. 


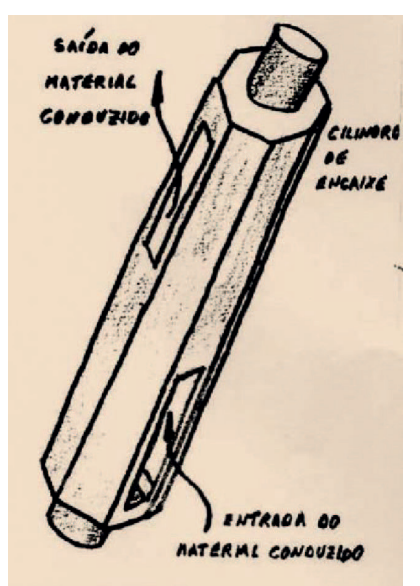

Figura 52: Tubulação sextavada com topos fechadose aberturas laterais.

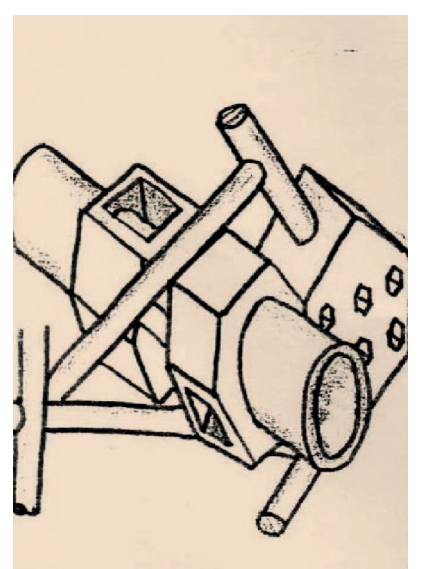

Figura 53. Aberturas da passagem da matéria sobre os cilindros dos círculos.

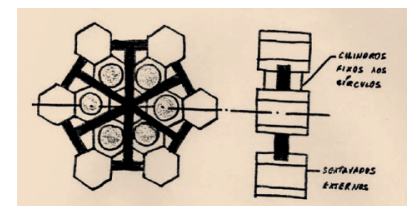

Figura 54: Círculo de feixes.
Finalizando esta seção, e capítulo, podemos concluir que a madeira é como um cano vazio, onde só existe parede celular e cavidade, pois todas as células não estão mais vivas.

\section{QUARTA PARTE}

\section{REALIZAÇÃO DO PROJETO}

\section{Aperfeiçoamento do modelo biónico videira}

Neste capítulo trabalharemos em cima dos debuxos anteriormente realizados para o possível modelo, realizando modificações no mesmo para acrescentálo mais algumas características da videira, bem como aperfeiçoar falhas já identificadas.

Comecemos imaginando que as tubulações demostradas na Figura 52, possuem forma sextavada, como o que realmente acontece com as células de condução e a condução seja feita radialmente.

A condução é feita radialmente e os tubos são fechados nas extremidades.

Este círculo de feixes hexagonais na qual os cilindros (I) servem como fixação para as mangueiras que devem encaixar nos cilindros das tubulações. Alguns destes cilindros devem ser ocos, permitindo a passagem do material conduzido de um lado para o outro do círculo de feixes. No mesmo desenho, os sextavados extremos são os elementos que suportam os feixes de fibras, análogos aos cubos imaginados.

As aberturas da passagem de matéria localizados nas tubulações, podem ser colocadas ou posicionadas nos cilindros fixos dos círculos, que adquirem uma forma nova, evitando problemas de vazamento de matéria nas tubulações ao se movimentar o mecanismo como um todo visto que o círculo mantém sempre a mesma posição em relação as tubulações.

O cilindro, agora apresenta em seu centro a forma sextavada com rasgos para encaixarem-se dentro das raias do círculo, sendo que sobre a forma sextavada encontram-se as aberturas de passagem da matéria, mantendo a trajetória espiral de condução.

A Figura 53 apresenta um sistema que possibilita curvar a tubulação, mostrando em corte uma espécie de manga flexível que se desloca no interior de um dos lados da tubulação, permitindo que mudanças de direções sejam feitas sem que ocorra vazamento matéria conduzida.

\section{A característica do crescimento no vegetal}

Como já vimos, as plantas crescem em diâmetro e em comprimento, na qual no corte do caule podemos identificar a idade de uma planta pelos círculos ou "manchas" mais claras e escuras. Então, imaginemos um modelo que comporte esta característica de crescimento, na qual vários cilindros de feixes, com raios (diâmetros), diferentes estão concentricamente posicionados, como mostra a Figura 55. Veja que os círculos apresentam a mesma forma, porém o número de tubulações nos cilindros externos é maior do que a dos internos, mas que 
se encaixam perfeitamente devido as formas hexagonais. Esta figura, lembra o caule cortado com suas "manchas", como se o modelo tivesse crescido em largura. Para dar o crescimento longitudinal ao modelo, imaginemos que os cilindros internos pudessem subir como em uma antena de automóveis, mostrada na Figura 55.

Em cada ponto onde termina um estágio de antena e começa o outro, estariam dois círculos de feixes como mostrou a Figura 56, seno o externo pertencente ao estágio inferior e o interno pertencente ao estágio superior.

O modelo do círculo de feixes, como percebemos, sofreu agora mais algumas alterações, como as raias que deixam de existir na forma compacta. Essa apresenta-se apenas com fios ou condutores de um estágio para outro num possível modelo com comandos elétricos aos quais, mais adiante, será citado, na seção final.

Outra mudança diz respeito aos feixes de fibras que se posicionavam nos tubos, que agora são substituídos por um único cabo. Um cabo de aço envolvido por uma mola flexivel por uma mola flexível para proporcionar o retorno do modelo a sua posição ereta.

Este novo sistema imaginado pelo estudo biónico, continua apresentando as características naturais encontradas na videira, adquirindo uma vantagem que é a maior facilidade para a sua possível construção.

\section{Automação do modelo}

Para que o modelo pudesse ser flexionado, sem que algum dos cabos fosse tracionado, na qual sistemas de roldanas posicionadas em cada um dos pontos onde fixa-se os cabos, permite que os mesmos sejam liberados a medida que a tração neles aumente ou diminua, e que ocorra uma deformação angular na mola de compensação que tem a função de enrolar o cabo em uma roldana e fazer com que o sistema retorne a posição inicial após retirado o esforço.

O tamanho do cabo e a máxima deformação da mola seriam os limitadores de flexão para o modelo. Para que se pudesse comandar a flexão do modelo, sem que um esforço manual seja feito. Nada mais é do que um êmbolo dentro de um cilindro, na qual o cilindro está envolvido por uma bobina (espira de corrente), ligado a uma fonte de energia (bateria). No momento em que o circuito é fechado, o êmbolo é atraído, flexionando o modelo biônico para o mesmo lado.

Um posterior sistema eletrônico de comandos poderia ser construído para comandar e coordenar possíveis movimentos desejados.

No próximo capítulo falaremos sobre a construção do primeiro modelo, observando as dificuldades encontradas para sua construção, as alterações feitas sobre as primeiras ideias e as novas soluções que poderão ser empregadas em determinados aspectos críticos do modelo. Tudo isso para deixar claro ao leitor as dificuldades encontradas e os passos que foram seguidos nesse projeto, em busca do exercício da Biônica. 


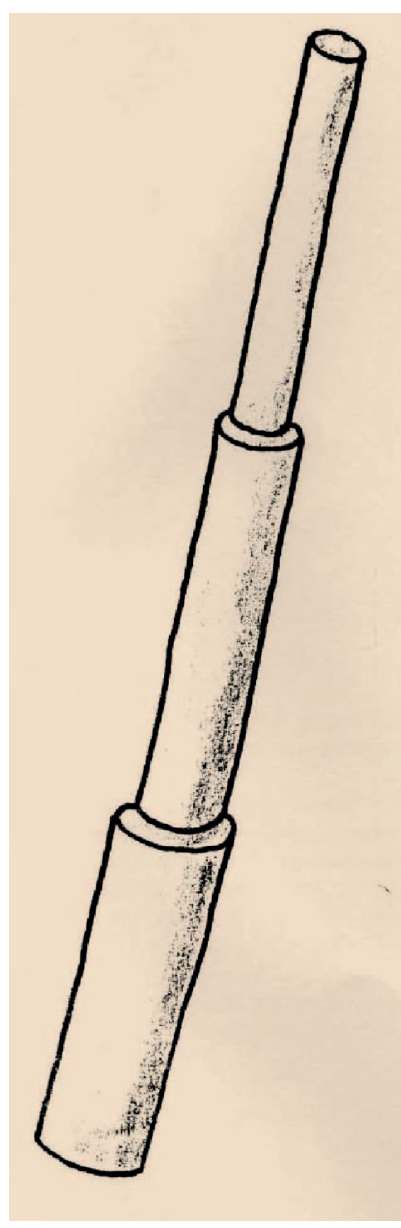

Figura 57: Antena de 3 estágios simulando o crescimento longitudinal do modelo.

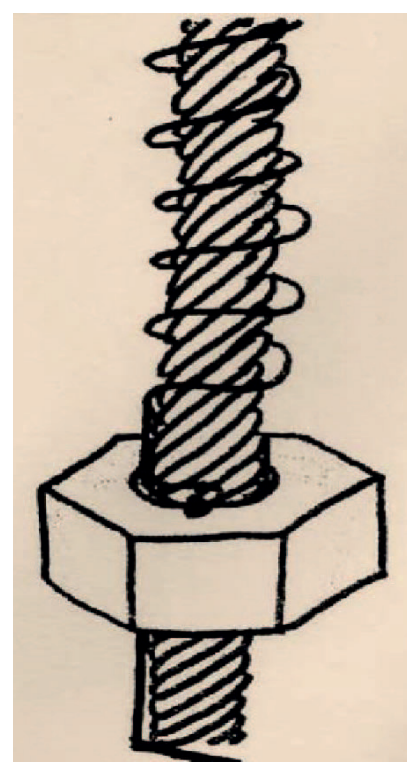

Figura 58: Cabo envolvido por uma mola.

\section{0 modelo biónico: construção do primeiro modelo biónico}

Para sairmos do papel e da teoria, passamos agora a construção do modelo biônico, o que nos possibilita visualizar as dificuldades e os erros realizados na idealização do projeto Inicial.

\section{Matéria-prima utilizada}

A matéria-prima utilizada foi o papelão de caixas de sapatos, devido a sua facilidade de obtenção com um custo praticamente zero, pois todos tínhamos a disposição em casa. Este mesmo material é de fácil manuseio e trabalhabilidade, o que não exigiu maquinário especial para a construção e modelagem das peças constituintes do modelo.

Também foi usada a cola tenaz, o elástico comercial, mangueiras plásticas e folhas de ofício como matérias-primas e acessórias.

O tenaz foi usado para selar e dar formatos determinados as peças. 0 elástico em substituição as molas e cabos que iriam propiciar o movimento do modelo com a sua volta a posição normal (ereta), automaticamente. As mangueiras plásticas para dar flexibilidade ao sistema.

E as folhas de ofício, como acabamento para as peças, visto que o papelão (matéria-prima), vem com diferentes colorações e propagandas de tênis e sapatos, o que não deixaria o modelo com uma coloração uniforme.

A folha de ofício, acabou por fim, em também aumentar a rigidez do modelo, pois a mesma era colada com tenaz em toda e superfície das peças.

\section{Ferramentas utilizadas}

Como ferramenta para construção das peças foram utilizadas canetas, lápis, tesoura, régua, esquadro, papel manteiga, compasso de ponta seca, faca, arame e muita criatividade

A caneta e o lápis para riscar sobre o papelão o formato das peças com o auxílio da régua e do esquadro. Esta demostra a importância da Biônica para a Engenharia, que é o exercício da criatividade. A tesoura para cortar o papelão no formato desenhado. 0 compasso de ponta seca para copiar medidas padrões. E a criatividade como ferramenta de integração das partes para que resultasse no modelo proposto.

\section{Tempo despendido para a construção do modelo}

O tempo computado para a aquisição do modelo básico, sem a introdução de princípios pneumáticos e elétricos para a sua automação, foi de aproximadamente dois meses e meio, para apenas obter a forma do modelo em 3D.

Como prol para que o modelo fosse construído rapidamente, temos a matériaprima de fácil manuseio e aquisição, e como contra o fato de não ter sido uma atividade isolada no andamento da pesquisa.

No entanto, o modelo obtido tem muitos pontos falhos que devem ser moldados e otimizados para a obtenção de um próximo ao ideal o que mostra a necessidade de se voltar a construção do modelo após novas concepções. 


\section{Aspectos desfavoráveis na construção do modelo biônicos}

O papelão era um material que não possibilitava a construção com uma precisão adequada e necessária para o bom funcionamento das partes móveis, como a que era necessário para a introdução de princípios pneumáticos, que exige uma perfeita vedação para que o ar possa ser comprimido, ou, no caso da utilização da hidráulica, para que não houvesse vazamento de fluído.

No caso da hidráulica, o modelo de papelão tem outra desvantagem, que é a de não poder estar em contato direto com o fluído, pois este danificaria o papelão, inutilizando-o.

E por último, a sua fragilidade, pois o modelo não pode ser submetido a grandes esforços.

Pontos falhos e aspectos não observados na idealização do primeiro modelo: Como não tínhamos definido uma aplicação para o modelo, nos detemos apenas aos pontos falhos de construção inerentes a execução das funções estruturais que os elementos da videira realizam, procurando identificar as limitações do modelo, como ângulo de curvatura máxima, torção máxima, elasticidade, porém não quantificando seus valores.

\section{QUINTA PARTE}

\section{APRESENTAÇÃO DO PROJETO}

\section{Fase final para a apresentação}

Como conclusão do trabalho executado, realizamos a estruturação e construção do relatório final com base no projeto de pesquisa inicial, levantando em conta tudo e todos os passos seguidos durante o trabalho procurando fazer um comentário transparente e fácil de entender a metodologia utilizada para o desenvolvimento de uma pesquisa Biônica. Também nos concentramos em elaborar o material que serve de apresentação do nosso trabalho em encontros de iniciação científica, congressos e eventos em geral.

\section{Processo de elaboração da dissertação}

0 processo de elaboração da dissertação vem sendo realizado desde o início da pesquisa, demonstrando-se o caráter contínuo e evolutivo que o mesmo apresenta, que evita desta forma a perda de informações e possibilita o contínuo melhoramento da tese. Porém, nesta fase final do projeto, executamos o fechamento da dissertação, ou seja, procurar condensar as informações obtidas e as conclusões chegadas de uma forma lógica e simples, que possibilitasse ao leitor da tese chegar as mesmas conclusões a que chegamos, e também, permitir que tenha outras ideias e soluções ao problema apresentado, diferentes das nossas. Ao todo, pode-se dizer que este processo de elaboração foi um trabalho lento, pois a ele foram dedicadas poucas horas diárias no decorrer das outras etapas, porém estas se tomaram sagradas, nem que fossem meros 20 minutos de trabalho, como catalogação e memorandos para serem analisados na etapa final.

Isto possibilitou o amadurecimento das ideias criativas para os elementos de pesquisa, e a consolidação dos conhecimentos adquiridos nas leituras de bibliografias, possibilitando melhor dissertar sobre as tarefas executadas.

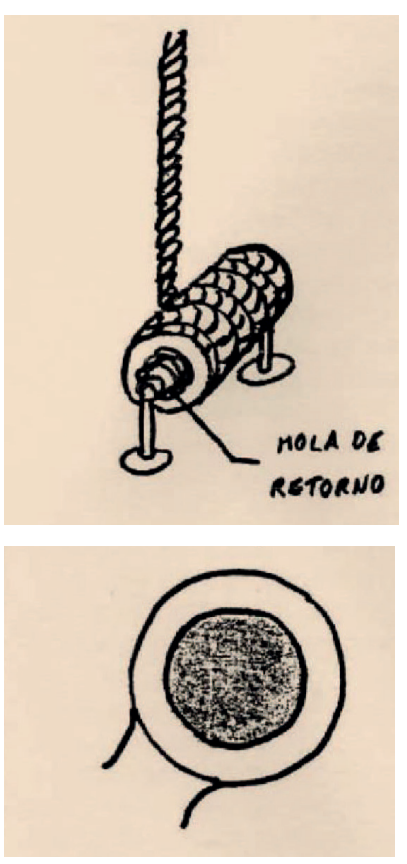

Figura 59: Representação usada para os cabos e molas.

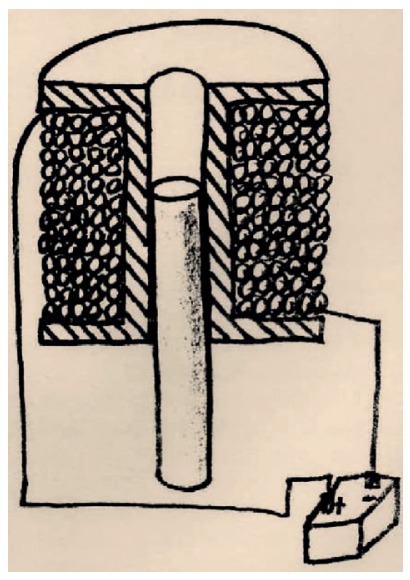

Figura 60: Êmbolo e espiras de corrente para flexionar o modelo. 


\section{Contribuição}

Como maior contribuição que esperamos ter deixado é a aprovação da Biônica como um excelente meio de:

- Estimular os estudantes de engenharia de desenho projetual em matérias básicas, por exemplo, física, química, biologia, matemática, desenho etc.

- Despertar a Biônica como uma técnica de longo prazo para o desenvolvimento da criatividade.

- Aumentar o grau de consciência dos envolvidos com a prática projetual da cultura material, por exemplo, engenheiros, arquitetos, desenhadores industriais, sobre o ambiente natural e os seus elementos como fonte de inspiração.

- Demonstrar que o questionamento sobre como se faz, como funciona, de que é feito, para que serve etc. é fundamental para que estudantes do terceiro grau ampliem os seus conhecimentos adquiridos na graduação e, desse juízo, possam tornar os seus pensamentos produtivos mais divergentes daquilo que se encontra dogmaticamente e previamente estabelecido, seja na prática diária de suas profissões ou nos caminhos da pós-graduação e do ensino superior.

Projetos de pesquisa em Biônica podem se tornar grandes fontes de divisas não só para industrialistas mas também para os países os quais apoiam este tipo de investigação. Portanto, esperamos que, pequenas empresas acreditem nesta técnica como modo de conseguir dar grandes saltos qualitativos em questões de desenvolvimento de tecnologia endógena e em desenvolvimento e crescimento industrial.

\section{AGRADECIMENTOS}

A equipe deste projeto, Professor Luiz Vidal Negreiros Gomes, Professor Amo Udo Dallmeyer Professor Leonardo Nabaes Romano, Professora Jumaida Maria Rosito, Professor Nilton Marquiori, Professor Adelino Alvarez, Professora Vera Siqueira, a Técnica Elcy Batistella, a colega Lilia Weber Brum, o colega Hugo Sário Scheid, por todas as ilustrações presentes nas figuras, e as instituições CNPq e CT/UFSM pela iniciativa na criação e participação no programa REENGE.

\section{REFERÊNCIAS}

1. GÉRARDIN, Lucien. Bionics. London: World University Library, 1968, p. 11. Nota: Esse livro foi escrito originalmente em francês. No ano de lançamento da edição inglesa (1968) o livro foi também publicado na Itália. Desconhecemos edição portuguesa desse trabalho.

2. David H. Offner (1923-2015), PhD e professor do Mechanical Engineering Department da University de Illinois. Em 1995, professor David Offner lançou o livro Design Homology: An Introduction to Bionics, com conteúdos que vão desde "Introdução à Homologia em Desenho Projetual até à Morfologia do Desenho Natural, passando por questões de projeto/desenho naturais". Disponivel em: https://books. google.com.br/books? redir_esc=y\&hl=ptBR\&id=YJQAAAAMAAJ\&focus=searchwithinvolume\&q=. 3. Von GIERKE, K. W. D.; OIESTREICHER, H. L. (Editors). Principles and Practices of Bionics. Slough: Technivision Services, 1970. 
5. Vide: GOMES, Luiz Vidal Negreiros. Minicurso Experimental em Biônica. In

6. GOMES, Luiz Vidal. Biônica e Atividade Projetual: Textos Básicos. Rio de Janeiro: PEP-COPPE/UFRJ, 1986, p. 111-120; e GOMES, Luiz Vidal. A Criatividade na Orientação Educacional de Desenhistas Industriais. Dissertação de Mestrado. Rio de Janeiro: COPPE/UFRJ, 30 de junho de 1986.

8. Righi (CDI/UFPE), Alfredo Oliveira (CDI/PUC-RJ), Francisco Lobo (CDI-UFMA); Carla Pantoja Giuliano (ULBRA-RS); Júlio van der Linden (UFRGS); João Luís Reith (PUC-RS).

9. Prof. Amilton Arruda do CDI/UFPE tinha, em 1994, proposta de criação de Laboratório de

10. Biônica em Pernambuco. Vide: LEON, Ethel. Um novo olhar sobre a Natureza. Globo Ciência. Rio de Janeiro: Editora Globo. Outubro de 1994, p. 24-31.

11. MILIDIÚ, Ruy L. Fundamentos das Redes Neurais. Livro de Minicurso do Congresso Nacional de Matemática Aplicada e Computacional (28 de agosto a 1 de setembro de 1995). Curitiba: UFPR/SBMAC, 1995, p. 8.

12. LEON, Ethel. Um novo olhar sobre a Natureza. Globo Ciência, p. 27-28.

13. SYLVÉSTRE, Jean P. Guide des Dauphins et Marsoins. Delachaux \& Niestle, 1990; apud PEREIRA, Alcmene A. Desenho Industrial e Biônica. Projeto de Pesquisa. Recife, 1993. 15p.

14. BENNATON, Jocelyn. O Que é Cibernética. São Paulo: Brasiliense, 1984, p. 49-55.; WIENER, Norbert. Cibernética e Sociedade. São Paulo: Cultrix, 1954.

15. OTTO, Frei. Una Nueva Arquitectura Natural. Mexico: Universidad Nacional Autonoma de México, s/d. 26p.

16. GHYKA, Matila C. El Numero de Oro. v. 1 e 2. Buenos Aires: Poseidon, 1968.

17. THOMPSON, D’Arcy W. Crescita e Forma. Torino: Boringhieril, 1969.

18. Di BARTOLO, Carmelo (A cura di). Strutture Naturali e Modeli Bionici. Milano: Istituto Europeu di Design, 1981.

19. LOTUFO, Vitor A. \& João M. A. LOPES. Geodésica e Cia. São Paulo: Projeto Editores Associados, 1986. 20. ARLOTTI, Giovana et alii. Strutture Gotiche, Strutture Naturali. Milano: Isttituto Europeo di Design, s/d.

21. Vanden BROECK, Fabricio. Las Estruturas en la Naturaleza y en la Técnica. Mexico: Universidade Autonoma Metropolitana de Mexico, 1986.

22. BONSIEPE, G. Teoría y Práctica del Diseño Industrial. Barcelona: Gustavo Gili, 1978, p. 124.

23. OFFNER, D.H. (The past) Experience often hold key to handling new ideas. Product Engineering, Nov.6, 1967, p. 88-90.

24. Vide: GOMES, Luiz Vidal. Criatividade e Design. Porto Alegre: SCHDs, 2011, p. 197-211.

25. SOARES, Danuzia; OLIVEIRA, Tiago M. de Oliveira. Longo fala sobre o engenheiro do próximo milênio. Centro de Tecnologia: Boletim Informativo. Santa Maria: CT/UFSM, Ano 2, n.4, março-abril de 1996.

26. GREEN, Donald R. Psicologia da Educação. 2a Ed. Rio de Janeiro: Zahar, 1972, p. 15-94. KAVANAGH, Terence. "Old Materials, New Materials". In GARNER, Steve; EVANS, Chris. Design and Designing. London: Berg, 2012, p. 325-341. SAWYER, Keith. Explaining Creativity. 2nd edition. Oxford: Oxford University Press, 2012, p. 63-106.

27. GOMES, Luiz Vidal: BROD JUNIOR; Marcos; MEDEIROS, Ligia. "Sobre Metódicas, Metodologias e Métodos para Projeto e Desenho de produto industrial". In WESTIN, Denise; COELHO, Luiz A. L. Estudo e Prática de Metodologia em Design. Rio de Janeiro: 2AB/Novas Ideias, 2011. p. 156-168.

28. GOMES, Luiz Vidal Negreiros. Minicurso Experimental em Biônica. In: GOMES, Luiz Vidal. Biônica e Atividade Projetual: Textos Básicos. Rio de Janeiro: PEP-COPPE/UFRJ, 1986, p. 111-120; e GOMES, Luiz Vidal. A Criatividade na Orientação Educacional de Desenhistas Industriais. Dissertação de Mestrado. Rio de Janeiro: COPPE/UFRJ, 30/06/1986. GOMES, L. Vidal. Criatividade e Design. Porto Alegre: SCHDs, 2011, p. 196-211.

29. OFFNER, David H. Bionics: A Creative Aid to Engineering Design. Mechanical Engineering. n. 96, 7th July 1974, p. 14-18; BOMBARDELLI, Carlo et alii. Como nasce un Produto Bionico. Milano: Centro Ricerche Strutture Naturali, Istituto Europeo di Design, 1985. ARRUDA, Amilton José V. Utilizo della classificazione naturale come elemento di studio biónico. Proposta Didática/Metodológica. Master in Bionica. Milano: Istituto Europeo di Design, dicembre, 1991, p. 22-26.

30. PAPANEK, Victor. Diseñar para el Mundo Real. Madri: H. Blume, 1977, p. 190; BONSIEPE, Gui. Teoría y Práctica del Diseño Industrial. Barcelona: Gustavo Gili, 1975, p. 125-134; VANDEN BROECK, Fabricio. Bionique, Biodesign. Lousanne: Ecole Cantonale des Beaux-Arts et d'Art Apppliqué, 1981, p. 3-5; VANDEN BROECK, Fabricio. Biodeseño: Una Filosofia de Proyectación. Manuscrito do autor. México, 1986, 16p

31. HUNTLEY, H.E. A Divina Proporção: Um Ensino sobre a Beleza na Matemática. Brasilia: Editora Universidade de Brasilia, 1985. 


\author{
32. Revista Cidade Nova, Ano XXVI ne 8, agosto de 1984. THAMES, Alfreda William. Botânica \\ Sistemática. 92 Edição. Ribeirão Preto: Gráfica e Editora Andrade, 1977; CUTTER, Elizabeth G. Anatomia \\ Vegetal. 22 Edição. São Paulo: Roca. \\ 33. HALLIDAY, David; RESNICK, Robert; WALKER, Jearl. Fundamentos da Física. 42. ed. Rio de Janeiro: \\ Livros Técnicos e Científicos, p. 174-177. \\ 34. RAO, A. G.; KOLI, Madhavi. Bamboo Craft Design. Mumbai: IIT, IDC, 1994. \\ 35. THAMES, Alfreda William. Botânica Sistemática. 9. ed. Ribeirão preto: Gráfica e Editora Andrade, \\ 1977, p. 15. \\ 36. O Brasil é país que mais tem espécies de margarida no mundo. São mais de duas mil, espalhadas \\ de Norte a Sul, um desafio e tatno para cerca de 40 profissionais que dedicam a vida a conhecer e \\ desvendar os mistérios de uma família tão vaiada que inclui alface, alcachofra e camomila. Cf., AZEVEDO, \\ Ana Lúcia. Profissão Margaritólogo. O Globo. Segundo Caderno, Sábado 16 de dezembro de 2017, p. 4. \\ 37. THAMES, Alfreda William. Botânica Sistemática. 9 ed. Ribeirão preto: Gráfica e Editora Andrade, \\ 1977, p. 15. \\ 38. CUTTER, Elizabeth G. Anatomia Vegetal. 20 ed. São Paulo: Roca, 1986, p. 70-75.
}

